\title{
KILL OR BE KILLED?: \\ USE OF DEADLY FORCE IN THE RIOT SITUATION
}

\begin{abstract}
What I want
What I am

What you force me to be

is what you are

For I am you, staring back from a mirror of poverty and despair, of revolt and freedom. Look at me and know that to destroy me is to destroy yourself. You are weary of the long hot summers. I am tired of the long hungered winters. We are not so far apart as it might seem. There is something about both of us that goes deeper than blood or black and white. It is our common search for a better life, a better world. I march now over the same ground you once marched. I fight for the same things you still fight for. My children's needs are the same as your children's. I too am America. America is me. It gave me the only life I know-so I must share in its survival. Look at me. Listen to me. Try to understand my struggle against your racism. There is yet a chance for us to live in peace beneath these restless skies. ${ }^{1}$
\end{abstract}

Since the major riot in Watts, California, in the summer of 1965, widespread rioting has occurred in the Negro ghettos of large American cities with ever-increasing frequency and magnitude. These outbursts are unlike other "race riots" that have occurred several times in American history, which were characterized by offensive action of white mobs against Negroes. ${ }^{2}$ The ghetto Negroes now take the offensive action, but that action is against community businesses and the police, two very specific targets, rather than against members of the white race in general.

The magnitude and unexpectedness of the Watts riot made people all over the world suddenly realize that significant numbers of Negroes in American ghettos had become so disillusioned with American society that they wanted to destroy as much of it as possible. This destructiveness was directed specifically at the two segnients of American society with which they came into the most frequent contact-the largely white police force and the white-owned commercial estabhishments within the ghetto. The slogan "Burn, Baby, Burn!" set the tone, and in spite of all the studies conducted and the speeches made since the Watts riot, that slogan has been shouted in the streets of the ghettos with ever-increasing frequency. The worst riot thus far, in terms of fatahities and property damage, was

1 Parks, The Cycle of Despair, LIFE, March 8, 1968, at 48.

2 Examples of this other type of riot include the New York Draft Riots in 1863 and the Detroit riot in 1943. There is evidence that police sympathy with the rioters prolonged both of these outbursts. President's CoMmar's on Law ENForcement and AdMinistration of Justice, Task Force Report: Crmare and 1Ts Impact-An Assessment 116-18 (1967). 
the Detroit riot of July 1967, the first of the recent disturbances to require federal army troops to restore the peace.

This Comment will deal only with the type of riot symbolized by Watts and Detroit. It will explore one of the many issues emerging from the recent riots-the use of deadly force by various law enforcement agencies summoned to contain the disturbances. In discussing this issue one must remember that the riots do not occur in a vacuum but rather are the product of deep and longstanding social and economic causes of discontent-poverty, unemployment, poor housing, lack of educationcauses which cannot be investigated here. The recommendations below dealing with the use of deadly force are certainly not offered as a complete solution, either to the problem of riots or to that of police-community relations in the Northern ghettos.

Resentment toward the police is one of the important causes of the riots. ${ }^{3}$ One purpose of this Comment is to examine low that resentment might be somewhat mitigated by changing police policy regarding the use of deadly force during the riots themselves. Much of the discussion will center on the legal and administrative standards which govern police practice in the general situation. This is because most of the same standards apply both in riot situations and in normal law enforcement. Riots, however, have elicited some special police practices and certainly pose some unique problems which will also be investigated in this Comment.

Much of the discussion will center exclusively on the local police departments, rather than the National Guard or federal troops. This is because contact between the local police and ghetto residents is constant and therefore provides a large field of investigation. Most of the standards which liave developed are in reference to the local police, because, obviously, the National Guard and federal troops have intervened only in emergency situations. Conclusions regarding the local police are often applicable to any other law enforcement agencies called in during the riot, but special problems regarding the National Guard and federal troops will also be explored.

The Detroit riot of 1967 has been chosen as illustrative of the riot situation, and virtually all factual references will be to this outburst. This choice was made for two reasons: First, it involved the use of federal troops, and thus raised a broader scope of legal problems; and second, because it was both the most extensive and most recent riot, the reader will more readily recall the events. The Detroit riot, however, represents only the most dramatic example of the problems surrounding the use of

3 See, e.g., id. at 116; Report of the National Advisory Commussion Disorders 299 (Bantam 1968). 
deadly force which have been present in all the recent riots. Therefore, the conclusions of this Comment are not limited to Detroit.

STAGES OF THE RIOT-DETROIT, 1967

On July 23, 1967, a riot began in Detroit, Michigan. Between that date and August 4, 1967, when the National Guard pulled the last troops out of the city, forty-three persons were killed, ${ }^{4}$ and the total loss in the riot areas from fire, looting, business interruption, and all other causes was approximately 144 million dollars. ${ }^{5}$ The incident that sparked the riot was a raid on an after hours drinking establishment at 3:30 a.m. on a Sunday morning. ${ }^{6}$ As a crowd gathered, the police arrested a total of seventy-three. The crowd became restless and angry, and that mood spread so quickly that within twelve hours it was evident that the city police could not handle the situation alone.

At 3:00 p.m. Sunday afternoon, Mayor Cavanaugh requested 200 Michigan state police for the Detroit area. At 4:20 p.m. Governor Romney committed the National Guard, ${ }^{7}$ and by 5:25 p.m. the first contingent of troops had arrived in the riot area. At 3:00 a.m. the next morning, July 24, Mayor Cavanaugh and Governor Romney announced that they had requested 5,000 federal troops from President Johnson to help restore order. The same afternoon the President sent his personal representative, Cyrus Vance, to Detroit and deployed 4,700 federal paratroopers to a nearby Air Force base. ${ }^{8}$ That evening Lieutenant General John Throckmorton assumed command of the federal troops and the National Guard, which he federalized at twelve midnight.

General Throckmorton announced at 1:45 a.m. Tuesday inorning,

4 Detroit Free Press, Sept. 3, 1967, § B, at 1, col. 1.

$\checkmark$ City of Detroit-Damage Assessment, (Table), Appearance of the City of Detroit Before the President's National Advisory Commission on Civil Disorders $\S D$, Table of Attachments, Aug. 15, 1967 (mimeo received from Mayor Cavanaugh of Detroit, on file with the California Law Review.)

${ }^{6} I d$. $\S \mathrm{B}$, Sequence of Events. All the chronological occurrences mentioned in the text accompanying notes 6-19 are from this source.

7 Mrce. Comp. Laws ANN. $\S 32.40$ (1967) gave the Governor this authority to call out the National Guard " $m$ case of riots, tumults, breaches of the peace or formidable resistance to the execution of the laws of the state, or of the United States withm the state, or reasonable apprehension of immediate danger therof, with which the civil authorities are unable to cope" on application of the mayor of the affected city. All states have similar statutes.

810 U.S.C. 331 (1964) gives the President this authority: "Whenever there is an insurrection in any State against it government, the President may, upon the request of its legislature or of its governor if the legislature cannot be convened, call into Federal service such of the militia of the other States in the number requested by that State, and use such of the armed forces, as he considers necessary to suppress the insurrection." 
July 25, that Detroit was divided for command purposes with federal troops on the East Side of the city and the National Guard on the West Side. At 9:12 a.m., fifty-four hours after the riot began, Mr. Vance announced that General Throckmorton was in charge of all local, state, and national forces in Detroit. This event completed the deloyment of civilian police authorities and military troops to Detroit.

The initial local police policy regarding the use of deadly force in the Detroit riot is unclear. During the first day of the rioting, for whatever reason, the police were not sliooting at looters, although substantial looting was occurring througliout the riot area. According to one news source, both civilians and police had the firm impression on Sunday that looters would not be shot.. ${ }^{9}$ However, on Monday at 9:30 a.m. Mayor Cavanaugh announced at a news conference that neither he nor the police commissioner had at any time forbidden the police to use available weapons, and that the police should use their individual juclgment about the extent of force necessary in each incident. ${ }^{10}$ On the same day a police superintendent gave permission to officers to return fire in sniper incidents. ${ }^{11}$ No deaths occurred on the first day of the rioting, but they mounted in the next several days as use of firearms increased. ${ }^{22}$

After federalizing the National Guard, General Throckmorton finally issued a clear order to the federal troops and National Guard regarding

9 Detroit Free Press, Sept. 3, 1967, § B, at 1, col. 2.

10 Sequence of Events, Monday, July 24, 1967, Appearance of the City of Detroit before the President's National Advisory Commission on Civil Disorders, § B, at 5, Aug. 15, 1967 (mimeo received from Mayor Cavanaugh of Detroit, on file with the Califormia Law Review).

11 See Detroit Free Press, Sept. 3, 1967, § B, at 1, col. 2.

12 Id. The same confusion as to initial orders regarding the use of firearms was present in the Newark riot of the summer of 1967. GOVERNOR's SELECT COMME'N ON CIVII DISORDER, REPORT FOR ACTION 133 (1968) [heremafter cited as REPORT FOR ACTION]. Testimony before this Commission indicated that until Thursday, July 13, 1967, no orders had been issued on the use of weapons, although the riot had begun the day before. Id. Police Director Spina's version of the issue reflects the confusion: "They say that Mayor Addonizio ordered me not to slioot. Actually I don't know where anybody ever got the idea that they couldn't shoot their guns. I was quite mystified. I heard a lot of shooting going on because I was in the area, and I didn't see any of our men shooting back. Then around six or seven liours after a lot of firing was going on some of the superior officers were coming to ine saying, "Do you think it is okay to shoot? When are we supposed to shoot?" The first couple of days that they asked me the question I didn't pay any attention to them and wondered why ... . they even asked me." Id. (emphasis added). The report goes on to say that Director Spina finally realized that his inen were under the impression that they had been given orders not to shoot, presumably two days later, and at that time he announced to his men over the pohice radio: "If you have a gun, whether it is a shoulder weapon or whether it is a hand gun, use it." Id. at 279. In such a complex, difficult situation, this order obviously lacks sufficient clarity and comprehensiveness. As a final irony, Spina said that he did not want looters shot, but he added that this order was never given! Id. at 133 . 
the use of deadly force. They were to unload, put their ammunition in their pockets and fire only on command from a superior officer. ${ }^{13}$ It appears, however, that about ninety percent of the Guardsmen did not obey this command, partially because of improper dissemination of the order and partially because of lack of disciphine. ${ }^{14}$

The most exhaustive investigation of the deaths that occurred during the riot gave this breakdown of the victims. ${ }^{15}$ Detroit police officers shot eighteen. Fourteen of these were confirnied looters, one a sniper, one a possible arsonist, and two were killed in a motel under unclear circumstances. The National Guard shot at least six of the dead. Five of these were innocent of any crime ${ }^{16}$ except possibly being in the riot area after orders to disperse. Five died in incidents which involved both local police and the National Guard, where it was inipossible to determine with certainty whose bullets were fatal. Four of these were innocent. ${ }^{17} \mathrm{~A}$ federal soldier killed one person. The rest of the deaths resulted from private citizens killing looters, fires, electric power lines, and other miscellaneous causes. Among the various law enforcement authorities one Detroit policenian and one National Guardsiman died, both shot accidentally by fellow officers. ${ }^{18}$ There was not a single death directly attributable to a sniper or an armed looter. ${ }^{19}$

13 Id. Cyrus Vance said that the troop commanders had been instructed to apply force in this order of priority: (1) unloaded rifles with bayonets fixed and sheathed; (2) unloaded rifles with bare bayonets fixed; (3) riot control agent CS-tear gas; (4) loaded rifles with bare bayonets fixed. Final Report of Cyrus R. Vance, Special Assistánt to the Secretary of Defense, Concerning the Detroit Riots, July 23 - August 2, at 18 (1967) (mimeo on file with the California Law Review) [hereinafter cited as Final Report of Cyrus Vance].

14 Detroit Free Press, Sept. 3, 1967, § B, at i, col. 2. General Throckmorton's Deputy Commander in Detroit gave the figure of $90 \%$. Hearings Before the Special Subcomm. to Inquire into the Capability of the National Guard to Cope with Civil Disturbances of the House Comm. on Armed Services, 90th Cong., 1st Sess. 5897 (1967) [héreinafter cited as Hearings on National Guard].

15 Detroit Free Press, Sept. 3, 1967, § B, at 1-5. The name of each victim and the circumstances of his death are given in detail.

16 Id. at I, col. 1 .

17 Id.

18 The Detroit police officer was Jerome Olshove, reported by the Detroit Free Press as the 21st victim, id. at 3, cols. 3-4, killed by a fellow officer's shotgun that went off in a scuffle with a prisoner arrested for looting.

The Guardsman was Larry Post, reported by the Free Press as the 42nd victim, id. at 5 , col. 5, caught in a crossfire between the National Guard and the occupants of a car and killed by the Guard. The occupants of the car turned out to be all white, and no guns were found. Authorities from the Guard claim that they were trying to run a roadblock. The three white youths were originally charged with assault with intent to commit unurder, reduced later to curfew violations.

19 See id. at $1-5$. 
$\Pi$

\section{IAW GOVERNING USE OF DEADLY FORCE}

\section{A. Self-Defense and Defense of Others}

Under both common and statutory law any person has the right to use any amount of force reasonably necessary for purposes of self-defense, up to and including deadly force when he reasonably believes he is threatened with death or serious bodily injury.$^{20}$ The law regarding defense of others is somewhat more variable, sometimes allowing a person to use deadly force to protect another from what he reasonably believes to be the threat of death or serious bodily injury, sometimes allowing him to act on reasonable belief in protecting certain close relatives, but requiring an actual threat in cases involving other persons. ${ }^{21}$ Policemen, guardsmen, and federal soldiers, of course, have these general rights to use deadly force. In addition, law enforcement authorities never liave a duty to retreat before using deadly force, and may always use this force for defense or others solely upon reasonable belief that they are being threatened with death or serious bodily harm. ${ }^{22}$ Given the function of the policeman to protect society from dangerous persons, these expansions of the right to use deadly force in self-defense or defense of others are clearly appropriate.

\section{B. Apprehension of Criminals and Quelling of Riots}

\section{Local Police Agencies}

Under the common law a policeman's right to use deadly force exceeds that of the ordinary citizen, in that he can use it when necessary to effect the arrest of a person reasonably believed to have committed a felony, thougli not a misdemeanor. ${ }^{23}$ The distinction between felonies and misdemeanors seems to have sprung from the fact that virtually all felonies were punishable by death in England as late as $1800,{ }^{24}$ thus making the penalty for trying to resist or escape arrest comparable to that for the offense itself.

\footnotetext{
20 See R. Perkins, Crmminal Law 885-87 (1957).

21 Id. at 909-12.

22 See Moder Penat Code, § 3.07, Comment at 55-56 (Tent. Draft No. 8, 1958).

23 E.g., Stinnett v. Virginia, 55 F.2d 644 (4th Cir. 1932); State v. Smith, 127 Iowa 534,
} 103 N.W. 944 (1905). The North Carolina Supreme Court has stated the policy behind the principle that an officer not be allowed to shoot at a misdemeanant, even if it is the only way to effect his arrest: "The accused is shielded in that event [the arrest of a misdemeanant], even from an attempt to kill with a gun or pistol, by the merciful rule which forbids the risk of human life or the shedding of blood in order to bring to justice one who is charged with so trivial an offense, when it is probable that he can be arrested another day and held to answer." Holloway v. Moser, 193 N.C. 185, 190, 136 S.E. 375, 378 (1927).

244 Brackstone, Conomentartes *94, *205. The specific date of 1800 is mentioned in $S$. Chapman, Police Firearms Use Pohicy 21-22 (1967) (mimeo sumitted to the President's Comm'n on Law Enforcement and Administration of Justicej). 
The laws of the various states generally perpetuate this distinction, either by statute or by case law. Usually, the relevant statutes are framed in terms of either justifiable homicide or permissible use of force by police. ${ }^{25}$ Many of these statutes contain wording sufficiently broad to permit all necessary force in arresting, whether for a felony or misdemeanor. ${ }^{2 b}$ In some states a proliferation of relevant but seemingly unconnected statutes confuses the entire area of permissible force for effecting an arrest. ${ }^{27}$ Some of the statutes himit the use of deadly force in preventing escape to situations in which someone has actually committed a felony, and thereby deem reasonable behief alone insufficient grounds. ${ }^{28}$ Others require only that the suspect have been cliarged with a felony. ${ }^{29}$ Still others require both that a felony be committed and that the person shot be the one who committed it. ${ }^{30}$ Statutes usually classify the offenses which are felonies either by the type of institution in which the offender can be incarcerated, ${ }^{31}$ or by the length of the term that can be imposed. ${ }^{32}$ Dangerous offenses such as drunk driving may be classified as misdemeanors, ${ }^{33}$ while less harmful once such as bigamy ${ }^{34}$ and petty larceny ${ }^{35}$ may be classified as felonies.

In most cases, despite variations in statutory language, the courts will not justify the action of a police officer if he uses deadly force to effect the arrest of a misdemeanant. ${ }^{36}$ They will, however, usually hold him justified when he uses it under a reasonable suspicion that a felony has been committed and that the arrestee lias committed it, and also demonstrates that it was necessary to effect the arrest. ${ }^{37}$

Thus, applying the general law governing use of deadly force to the

25 See Moder Penat Code, § 3.07, Comment at 53-54 (Tent. Draft No. 8, 1958).

26 E.g., CaI. Pen. Code $\S 843$ (West 1955).

27 E.g., CaL. Pen. Code $\$ \S 196,843$ (West 1955). For a thorough discussion of the present California law governing the use of deadly force by police officers, and the confusion created by use of unclear statutory language, see D. Green, Use of Deadly Force in Effecting Arrests 8-33 (1967) (nimeo prepared for the California Assembly Comm. on Criminal Procedure, on file with the California Law Review).

28 E.g., Nev. Rev. Stat. \$ 200.140 (1961).

29 E.g., ARIz. Rev. Stat. § 13-461(2) (c) (1956).

30 E.g., ATASKa StaT. § 11.15.090(4) (1962); ORE. Rev. Stat. § 163.100(1)(c) (1967).

31 E.g., Cat. Pen. Code $\S 17$ (West 1955); Mich. Stat. AnN. § 28.197 (1962).

32 E.g., 18 U.S.C. $\S 1$ (1964).

33 E.g., Car. Pen. Code $\$ 367$ (d) (West 1955).

34 E.g., MTCH StaT. ANN. $\$ 28.694$ (1954). In fact, in Michigan even mere advocacy of bigamy is a felony. $I d$. $\$ 28.696$.

35 See, e.g., Mich STAT. ANN. \$ 28.592 (1954).

36 E.g., Weissengoff v. Davis, 260 F. 16, 19 (4th Cir.), cert. denied, 250 U.S. 674 (1919); Tuttle v. Forsberg, 331 피. App. 503, 73 N.E.2d 861 (1947); Davis v. Hellwig, 21 N.J. 412, 122 A.2d 497 (1956).

37 E.g., Vaccaro v. Collier, 38 F.2d 862, 868 (D. Md. 1930); Murphy v. Murray, 74 Cal. App. 726, 241 P. 938 (1925); People v. Kilvington, 104 Cal. 86, 37 P. 799 (1894). 
riot situation, it is legally justifiable for the police to shoot at looters if that is the only way to effect their arrest where, as in Michigan, larceny from a store is a felony. ${ }^{38}$ Of course, if the looter is the one who breaks and enters the store, he is guilty of burgalry, which is almost always a felony. ${ }^{39}$ As for smipers, the police can use deadly force against them to effect their arrests, since assault with a deadly weapon and attempted murder are certainly felonies. Therefore, unless the officers created an unreasonable risk to bystanders in their use of deadly force, in which case the courts might find civil or criminal neghigence, ${ }^{40}$ the deaths caused by their shooting at looters and snipers during the Detroit riot were legally justified.

In addition to the laws governing police use of deadly force in all situations, some thirty-three states, including Michigan, now have special legislation sanctioning use of deadly force in case of riot. ${ }^{41}$ These statutes are typically found in the provisions governing justifiable homicide or in the entmeration of powers of the National Guard during riot or insurrection. The wording of these statutes is usually quite general, ${ }^{42}$ and such generahity indicates that in the legislatures' judgment, the necessity of suppressing a riot is enough in itself to justify the use of deadly force. There are no cases construing these statutes, but if taken on their face, they justify the killings of all the victims in the Detroit riot, including any shot as looters with no reasonable ground to believe that they were

38 Mitcr. Stat. ANN. \$ 28.592 (1954).

39 E.g., CAI. PEN. CODE $\$ \S$ 459-61 (West 1955); Miter. Stat. ANN. $\$ \S 28.305-06$ (1954).

40 See, e.g., Dyson v. Schmidt, 260 Minn. 129, 109 N.W.2d 262 (1961); Davis v. Hellwig, 21 N.J. 412, 122 A.2d 497 (1956). All these cases involve the policeman in lis everyday activity. In the riot situation, the courts would be much less likely to find an unreasonable risk to bystanders, and would probably reason that the countervailing danger posed by the rioters themselves would be greater.

41 Modex Penai Code, § 3.07, Comment at 68 (Tent. Draft No. 8, 1958).

42 E.g., CaL. Pen. Code § 197(4) (West 1957): "Homocide is . . . justifiable when committed by any person ... when necessarily committed . . . by latwful ways and means ... in lawfully suppressing any riot, or in lawfully keeping and preserving the peace."; Mrcer. StaT. ANN. $\$ 28.795$ (1962), which says that homicide is justified if any spectator or other person is killed by reason of the efforts of two or more magistrates or officers, or by their direction, to disperse or arrest persons engaging in tiot or unlawful aśsembly.

The Modè Peivai Code, $\S 3.07$ (5) (a) (ii) (2) (Tent. Draft No. 8, 1958), includes a provision justifying liomicide in the suppression of a riot: "[Use of deadly force is not justified unless] the actor believes that the use of such force necessary to suppress a riot or mutiny after the rioters or mutincers have been orderèd to disperse and warned, in any particular manner that the law may require, that such force will be used if they do not obey."

The wording of this provision is an improvement over that of the other two examples given in this footnote because it does not use such general terms and it includes a requirement of warning that deadly force is about to be used. The framers of the Model Penal Code justified inclusion of this provision thus: "As to the policy of the provision, it is arguable that it is uo longer uecessary. Firmg on rioters or mutineers will ordinarily be justifiable if it is really necessary on the simple ground of self-defense. The police are not under a duty 
actually looting, and any shot in the general searches for snipers in spite of an unreasonable risk to bystanders. Therefore it appears that the police policies and actions involving the use of deadly force were legal under the present state of the law, barring the killings whicl, according to witnesses' accounts, involved specific criminal intent. ${ }^{43}$

\section{Federal Troops and National Guard}

The courts of the states and federal government have generally held that the use of military forces in situations of domestic violence, ${ }^{44}$ short of all-out war, does not justify the suspension of the operations of civilian courts and the substitution of military tribunals, whether or not there has been a declaration of martial law. ${ }^{45}$ This section, then, is concerned with the law applied by the civilian courts to govern the actions of federal troops and Guardsinen during a riot situation. ${ }^{46}$

to retreat and ordinarily they should not and do not resort to arms unless their safety is in jeopardy if they attempt to stand their ground against the rioters. Yet, there is danger here that they may be overwhelmed and rendered impotent by the sheer weight of numbers. This is the case for the imclusion of the provision and we submit that it has force." MODEL PENAI Code, $\$ 3.07$, Comment at 68 (Tent. Draft No. 8, 1958).

This justification, however, is illogical for the simple reason that if the police were "overwhelmed and rendered impotent by the sheer weight of numbers" of rioters attacking them, they would be able to use deadly force in self-defense, since presumanbly under these circumstances they would be threatened with death or serious bodily harm. Note that the provision was drafted seven years before the first major riot of the recent type and the consequent controversy over just how much force the police should use in these riots.

43 Detroit Free Press, Sept. 3, 1967, § B, at 1, col. 1, reported that criminal intent was a possible element in seven of the deaths of the Detroit riot.

44 Martin F. Richman, First Assistant, Office of Legal Counsel, U,S. Department of Justice has defined a situation of domestic violence in this way: "[E]ssentially circumstances where violence is against State law and against State authority-that is, where the violence is being opposed in accordance with the normal rule of State and local responsibility for ordinary law enforcement. That is the domestic violence type of situation. In distinction to that is the situation where the State itself is opposed or indifferent to the enforcement of Federal law, or where the State is unable to assure the enforcement of Federal law." Hearings on National Guard, supra note 14, at 5819.

45 Duncan v. Kahanamoku, 327 U.S. 304, 322-34 (1946); Sterling v. Constantin, 287 U.S. 378, 400-01 (1932); Bishop v. Vandercook, 228 Mich. 299, 309-10, 200 N.W. 278, 280-81 (1924) ;Ex parte McDonald, 49 Mont. 454, 476-77, 143 P. 947, 954-55 (1914); Commonwealth v. Shortall, $206 \mathrm{~Pa}$. 165, 172, 55 A. 952, 956 (1903). But see In re Boyle, 6 Idaho 609, 611-13, 57 P. 706, 707 (1899).

Mr. Richman, U.S. Department of Justice, in a letter to the House Subcommitee on Armed Services, noted the possibility of state or federal court martial of a member of the Guard or of the regular armed forces for any offense committed while assigned to quell domestic violence. A court martial is possible only as long as the soldier or guardsman remains in the service of the United States or the state. Hearings on National Guard, supra note 14, at 5836-37. To this extent, then, the military courts are in operation during and after situations of domestic violence.

46 Neither the President of the United States nor the Governor of Michigan declared martial law at any time during the Detroit riot, nor has there been any such declaration in 
(a) Federal law.-Under the present law it is not completely clear whether federal or state law would govern in a suit against a federal soldier for his activities during a domestic riot. If the plaintiff brought the action in a state court "on account of an act done under color of [the soldier's] office or status" the defendant would have the right to remove it to the federal district court of the area. ${ }^{47}$ In this case, neither the Constitution nor the federal statute which authorizes the President to send in federal troops upon the Governor's request ${ }^{48}$ dictates the rule as to which law applies. Therefore, the court hearing the case would have to determine whether its issues fall within the ambit of federal common ${ } \mathrm{law}^{40}$ and require a uniform federal standard. ${ }^{50}$ The basis of this decision should be whether the issues involved in the case are essentially of local or federal interest:

[Erie's] object and effect were . . . to bring federal judicial power under subjection to state authority in matters essentially of local interest and state control.

Conversely, there was no purpose or effect for broadening state power over matters essentially of federal character or for determining whether issues are of that nature. . . . Accordingly, the Erie decision ... [did not] ... bring within the governance of state law matters exclusively federal, because made so by constitutional or valid congressional command, or others so vitally affecting interests, powers and relations of the Federal Government as to require uniform and national disposition rather than diversified state rulings. Hence, although federal judicial power to deal with common-law problems was cut down in the realm of liability or its absence governable by state law, that power remained unimpaired for dealing independently, wherever necessary or appropriate, with essentially federal matters,

any of the recent riots in the Northern Negro ghettos, so this Comment will not deal with what the effect of such a declaration would be. For general descriptions and opinions on the permissible scope of power of the military authorities during a state of martial law, see C. Fatratan, The Law of Martial Rule (2d ed. 1943); B. Rich, The Prestdents and Civil Disorders 208-11 (1941); Ballantine, Unconstitutional Clains of Military Authority, 5 J. AMr. INST. CRIM. LAW \& CRIM. 718 (1914).

4728 U.S.C. \& 1442a (1964).

4810 U.S.C. $\$ 331$ (1964). For text of this statute see note 8 supra.

49 Professor Wright points out that there is still such a thing as federal common law, with various complex rules governing its application: "Whether state law or federal law controls on matters not covered by the Constitution or an Act of Congress is a very complicated question, which yields to no simple answer in terms of the parties to the suit, the basis of jurisdiction, or the source of the right which is to be enforced. Whenever the federal court is free to decide for itself the rule to be applied, and there are many such situations, it is applying, or making, 'federal common law.'" C. Wrughr, Federac Courts 214 (1963). For this general discussion of the subject of federal common law, see id. at 213-18.

50 The Supreme Court in Clearfield Trust Co. v. United States, 318 U.S. 363, 367 (1943), emphasized the need for uniformity as one criterion governing whether a federal standard should apply to the subject matter at hand. 
even though Congress has not acted affirmatively about the specific question. ${ }^{51}$

At least with regard to the federal troops, it seems that the courts could easily deem the legal issues arising from their actions during riots to be "essentially federal," since they are under direct federal command and ultimately responsible only to the President. ${ }^{52}$ The confusion resulting from soldiers taking their orders from federal authorities who may or may not be acting according to the standards of state law would seem to entitle them to the protection of a umiform federal standard of which their officers could inform them and by which they could govern their own actions. However, there has been no decision on the subject of federal troop intervention in domestic disturbances since Erie Railroad Company v. Tompkins ${ }^{53}$ in 1938, so the issue remains unresolved.

If the courts were to apply a federal standard to the actions of individual soldiers and officers, it would probably be the one developed in early cases $^{54}$ concerning the responsibility of enlisted men when they are obeying the orders of a superior officer. This standard dictates that if a subordinate acts solely with the intent to carry out an order, and does not show vindictiveness or use more force than necessary under the circumstances, he will not be civilly or criminally liable unless the order is "palpably" illegal:

Except in a plain case of excess of authority, where at first blush it is apparent and palpable to the commonest understanding that the order is illegal, I cannot but think that the law should excuse the military subordinate when acting in obedience to the orders of his commander. . . . The first duty of a soldier is obedience, and without this there can be neither discipline nor efficiency in an army. If every subordinate officer and soldier were at liberty to question the legality of the orders of the commander, and obey them or not as they may consider them valid or invahid, the camp would be turned into a debating school, where the precious moment for action would be wasted in wordy conflicts between the advocates of conflicting opinions. ${ }^{55}$

51 United States v. Standard Oil Co., 332 U.S. 301, 307 (1947).

52 "When troops are used within the continental limits of the United States the only civil authority to whose orders they are subject is the President, acting through the Secretary of War. They should, of course, be used in concert, so far as may be practicable, with the civil officers of the State or federal government. And the President may direct thein specifically to lend their support to a State or federal magistrate. But the chain of command remains unbroken, and in no proper sense may they be referred to as acting in subordination to local civil officers." C. FATRMan, The Law of Martial Rule 37-38 (2d ed. 1943).

53304 U.S. 64.

54 In re Fair, 100 F. 149 (1900); United States v. Clark, 31 F. 710 (1887); McCall v. McDowell, 15 F. Cas. 1235 (No. 8673) (C.C.D. Cal. 1867).

$55 \mathrm{McCall}$ v. McDowell, 15 F. Cas. 1235, 1240 (No. 8673) (C.C.D. Cal. 1867). 
Under this standard individual federal soldiers would probably be justified in killing rioters so long as they were acting according to orders and without malice.

However, there is no specific federal standard governing the amount of force which the commander may legally order in a domestic riot situation. There are no federal stautes governing the amount of force which federal troops may use in riots effective at the present time, and there is no appreciable amount of federal common law on the subject.

The National Guard, in its unfederalized state, has a dual character as an "integral part of the first line defenses of the United States," a state peacekeeping force in peacetime. ${ }^{57}$ Federal law governs the recruitment, pay, and equipment of National guardsmen and they drill in armories largely paid for with federal funds. ${ }^{58}$ On the other hand, when the Governor of a state calls out the National Guard to aid local police agencies in domestic emergencies, he is the highest commander as long as federalization does not occur. ${ }^{59}$

In Maryland v. United States, ${ }^{60}$ the United States Supreme Court stated that guardsmen acting either in a military or civil capacity were employees of the state rather than the federal government, since the state authorities appointed them and exercised immediate control over them. ${ }^{01}$ Thus, although in this particular case the decision meant that the plaintiffs were without a remedy because the state of Maryland had not waived its sovereigu immunity, the Court held that a guardsman is not subject to an action under the Federal Tort Claims Act. ${ }^{62}$ This decision is an indication that as long as there is no federalization of a state's National Guard, state law, rather than federal law, applies to its actions.

The same opinion inentioned the fact that the Governor of Maryland was in command of the National Guard except when called into active federal service, ${ }^{63}$ thus raising the possibility that had the Guard been federalized at the time the cause of action arose, federal law would have been applicable. This result is consonant with the reasoming of the case, since when the Guard is federalized, the federal authorities exercise immediate control over it, just as they do over the federal troops. ${ }^{04}$ However, since the courts liave not yet determined that a uniform federal standard

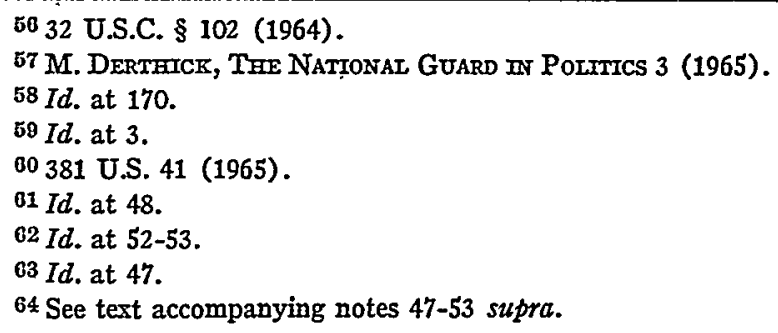


governs the actions of regular federal troops, federalized guardsmen, or guardsmen in state service, and since they would be less likely to do so in the last of the three, the applicable state law governing military use of force in the riot situation must be examined.

(b) State law-Under state law, like federal law, a guardsman is generally not criminally or civilly liable when he obeys an order without malice unless that order is "palpably" illegal. ${ }^{65}$ The few cases on the subject of how much force his commander may order him to use, however, are in conflict as to whether the law which governs police officers is in force, or whether the Governor has some added emergency power to allow the guardsmen to take actions not normally permissible under regular state law. Three of these cases, including the one relevant Supreme Court decision, seem to be in favor of allowing the Governor extensive additional power. ${ }^{8 B}$ These cases indicate that the Governor and his military commander have total discretion to use whatever force they deem necessary, and evolve no standard to control this discretion. ${ }^{67}$ However, four state supreme court cases, all more recent than the 1909 United States Supreme Court decision, authorize no more action by the Governor in commanding the National Guard than state law allows to all other law enforcement agencies as long as the civil authorities are still functioning. ${ }^{68}$

These cases are all from the early part of the century and pertain to situations radically different from the nodern riots in the Northern ghettos. The violence which occurred usually sprang from clashes between groups, such as strikers and strikebreakers. It did not involve entire

${ }^{65}$ See, e.g., Commonwealth v. Shortall, 206 Pa. 165, 176, 55 A. 952, 957 (1903).

Bo See Moyer v. Peabody, 212 U.S. 78 (1909); In re Boyle, 6 Idaho 609, 57 P. 706 (1899); Commonwealth v. Shortall, 206 Pa. 165, 55 A. 952 (1903).

67 Two of these cases speak in terms of martial law "to a limited extent" and "qualified" martial law. In re Boyle, 6 Idaho, 609 612, 57 P. 706, 707 (1899); Commonwealth v. Shortall, $206 \mathrm{~Pa}$. 165, 176, 55 A. 952, 954 (1903). But the closest any of them comes to a specific standard is that whatever measures are necessary in the opinion of the Governor or his military commander are justified. The United States Supreme Court said in 1909: "When it comes to a decision by the head of the State upon a matter involving its life, the ordinary rights of individuals must yield to what he deems the necessities of the moment." Moyer v. Peabody, 212 U.S. 78, 85 (1909). In 1903 the Pennsylvania Supreme Court had come to the same conclusion: "So far as [the commanding officer's] powers for the preservation of order and security of life and property are concerned, there is no limit but the necessities and exigency of the situation." Commonwealth v. Shortall, $206 \mathrm{~Pa} .165,172,55 \mathrm{~A} .952,955$ (1903).

${ }^{08}$ Franks v. Smith, 142 Ky. 232, 250-51, 134 S.W. 484, 492 (1911) ; Bishop v. Vandercook, 228 Mich. 299, 309 10, 200 N.W. 278, 280-81 (1924); Fluke v. Canton, 31 OkIa. 718, 739, 123 P. 1049, 1058 (1912); Manley v. State, 62 Tex. Crim. 392, 400, 137 S.W. 1137, 114041 (1911). The Texas Supreme Court stated specifically in 1911 that, "In times of peace a militiaman has no more right to take buman life than any other officer or citizen." Id. at 400,137 S.W. at 1141. 
communities with men, women, and children alike on the streets and in the homes, with participants and nonparticipants inextricably mixed, as is the case with the modern riots. The state courts at present have no clear, relevant standard to apply to this situation, which is quite new to American life.

III

\section{RECOMMENDED CHANGES IN IAW}

\section{A. Inadequacies of the Present Law}

In statutes regarding the general use of deadly force by police officers, the rigid distinction betwen felonies and misdemeanors has no place in modern law. The reason for this distinction is historical, and the conditions which brought it about no longer exist. Capital punishment has been abolished in many states ${ }^{69}$ and where it still exists, it is usually a possible penalty for only a few very serious offenses. ${ }^{70}$ Therefore, killing a suspected felon while trying to arrest liim is no longer commensurate with the penalty which he would face upon conviction. Also, the distinction has generally become blurred and arbitrary, with no particular relation to the seriousness of the offense. ${ }^{71}$ Thus, since the original reason for the distinction has become outmoded, and the distinction itself has become unclear, it is necessary to examine what the modern purposes should be for allowing a policeman to use deadly force to effect an arrest, and what law can best fulfill these purposes.

One of the reasons for allowing police officers to use deadly force to effect arrests is to protect members of society against persons who would be dangerous if they went free. In the riot situation this interest requires that the policeman be able to use all necessary force, up to and including deadly force, to apprehend snipers because they pose an immediate physical threat to police, firemen, and other citizens in the vicinity. The same reasoning applies to rioters who are using or threatening to use deadly force against someone to break into a store and loot it, because they also pose an immediate threat of death or serious bodily injury to another person. Under the present law in most states the policeman can use deadly force in both these instances, when the suspect has already committed the offense ${ }^{72}$ or when he is about to or in the course of committing it. ${ }^{73}$

69 See H. Bedad, The Death Penatity in America 12 (1964).

T0 Id. at $13-32$.

71 For instance, in California possession of marijuana, a crime which seldom involves a threat of death or serious bodily harm, is a felony, CAL. HEALTH \& SAFETY CODE $\$ 11530$ (West 1964), but drunken driving, an offense which can obviously cause very serious physical harm to others, is a misdemeanor, CaL. PeN. Code $\$ 367 \mathrm{~d}$ (West 1955).

72 See text accompanying notes 23-39 supra.

73 See R. PERkens, Crminal LAw 880-83 (1957); Comment, Justification for the Use 
But the present state of the law allows a broader scope of permissible use of deadly force than is consistent with the purpose of protecting society from dangerous criminals, because generally the policeman may use deadly force to prevent the escape of any person who he reasonably believes has committed a felony. He need make no judgment as to whether the person poses a threat of physical harm to others; he need not even know whether the person is armed with a dangerous weapon. For instance, if larceny is a felony, an officer can shoot a suspected looter fleeing in panic, unarmed and empty handed, from a store previously opened. Therefore, the issue becomes whether the added increment of power given to the policeman is worth the added threat to human life, be it only the life of a suspected felon.

Two factual premises often assumed for the present policy of allowing police to use deadly force to apprehend a felon are that it will deter criminals from trying to escape and that it does not involve much risk to innocent persons. These are the underlying premises of Professor Waite's opposition to any change in the present law:

We can give the officer the privilege of arresting without jeopardizing the life of an innocent citizen since we say that the citizen runs no risk if he simply submits to the inconvenience of the arrest. If he is an innocent citizen the officer cannot shoot, remember, until he has reasonable ground to believe that the citizen knows the arrest is being effected. If he is an innocent citizen he will not have any reason for not submitting to the arrest. If he is not an innocent citizen, he ought to be arrested. ... If we pass ... [ [the proposed section of the Model Penal Code] ... we say to the criminal, "You are foolish. No matter what you have done you are foolish if you submit to arrest. The officer dare not take the risk of shooting at you. If you can outrun him, outrun and you are safe." We say to the officer, "You dare not shoot at the fleeing criminal." We say to the criminal, "Outrun him if you can. If you are faster than he is you are free and God bless you." I feel entirely unwilling to give that benediction to the modern criminal. ${ }^{74}$

of force in the Criminal Law, 13 Stan. L. Rev. 566, 577 (1961): Modex Penal Code $\$ 3.07$ Comment 57 (Tent. Draft No. 8, 1958). The authors point out that deadly force to prevent the commission of a felony is only permissible if the threatened felony is dangerous, or the violent type for which force is essential for its purpose. The author of the Counment also noted the disparity between limiting the use of deadly force to prevent the commission of a felony in this fashion, yet allowing it to prevent the escape of any felon: "The failure to limit the types of felomes which merit the use of deadly force [to prevent the felon's escape] is a unique literalness in the law of justification, in view of the common-law limitations on the right to kill to prevent the commission of a felony. Under the common law, this dichotomy resulted in a broader privilege to use deadly force in arresting a felon than could be used to prevent his criminal act. It is notable that this result differs from the rule regarding non-deadly force, where the privilege is the same for prevention and apprehension." Comment, supra, at 580 .

74 Quoted in J. Michael \& H. Wechsler, Crtaminal Law and Its Administration 8182 n.3 (1940). 
Neither of the factual premises is entirely accurate. In the first place, it is at least questionable that legal authorization of police use of deadly force will deter criminals from trying to escape. Conflict has raged for many years over whether a person's knowledge of the serious consequences he faces if apprehended will deter him from committing a particular crime, especially in the debates about capital punishment. ${ }^{76} \mathrm{Nu}-$ merous studies of the deterrent value of capital punishment by experts in the areas of criminal psychology and penology have resulted in conflicting conclusions. ${ }^{76}$ However, there is no convincing statistical evidence that capital punishment deters. ${ }^{77}$ The same uncertainty would undoubtedly surround the analogous subject of the deterrent effect of possible police use of deadly force.

In the second place, there is considerable risk to innocent persons involved in the present policy. The proposition that if a citizen is innocent he will never try to flee arrest is doubtful at best. In the Negro ghettos of the United States, where police use of deadly force occurs most frequently, the inhabitants have a longstanding distrust and fear of all policemen.$^{78}$ Fear of harassment, of verbal or physical abuse, or merely of being found in any suspicious circumstances may prompt them to flee upon the approaich of an officer. Since the officer may legally fire upon reasonable belief that the suspect committed a felony, he mayy easily wound or kill this fleeing person even if he is innocent. This situation is even more likely to occur during a riot, when rumors and stories circulate about the actions pohice are taking. In fact, innocent persons died this way in the Detroit riot. $^{79}$

75 The California Supreme Court has recognized the uncertainty of the proposition that capital punishment is an effective deterrent: "In the present case, however, the prosecutor went beyond merely urging severe punishment. He stated as a fact the vigorously disputed proposition that capital punishment is a more effective deterrent than imprisonment. . . . There is thus no legislative finding, and it is not a matter of common knowledge, that capital punishment is or is not a more effective deterrent than imprisonment." People v. Love, 56 Cal. 2d 720, 731, 366 P.2d 33, 38-39, 16 Cal. Rptr. 777, 782-83, rehieärìng denied, 56 Cal. 2d 748, 366 P.2d 809, 17 Cal. Rptr. 481 (1961) (emphasis added).

76 For a partial list of these studies see People v. Love, 56 Cal. 2d 748, 757-58, 366 P.2d 809, 815, 17 Cal. Rptr. 481, 487 (1961).

77 This is the general conclusion of the author of a comprehensive statistical study done by comparing in various ways the states that retain the death penalty with the states that have abolished it. Sellin, The Death Penalty, in Moder Penat Cone, at 1-84 (Tent. Draft No. 9, 1959).

78 See tert accompanying notes $135-44$ infra.

79 The Detroit Free Press, Sept. 3, 1967, $\S$ B, at 5, reports two victims whose deaths appeared to have occurred in this fashion. One was George Talbert, the 40th victim of the riot, who was shot by the National Guard while he was walking down the street, although he was unarned, not out after curfew, had nothing in his arms, and there were no stores in the immediate area. The official report of the Guard was that he had refused to halt when ordered to do so. Id. at cols. 2-3. 
However, the risk to human life is not only relevant in regard to the innocent, but also to those who are in fact guilty of a felony, a fact Professor Waite neglects to mention. By allowing the police to fire on any felon fleeing arrest the law permits the killing of people who would not ordinarily receive the death penalty - in fact, people wlose suspected crime often involves no threat to human hfe. Fleeing arrest itself is a felony in many states, but few would suggest that this crime should carry the death penalty in order to deter others from its commission. In fact, no state legislature feels that deterrence is such an important interest that it will assign the death penalty for any crime less serious than one involving danger to human life. ${ }^{80}$ Because of the widespread looting and disorder, the riots result in the deaths of more people who are guilty only of minor felonies which involve no danger to human life. The general risk to luman life inherent in the present law of police use of deadly force more than outweighs any deterrent value it might have.

Even assuming the accuracy of the two premises, however, the present policy is unwise. Permitting the use of deadly force to bring a criminal to trial represents a misunderstanding of the proper role of the police in a deniocratic society. An unspoken, and perliaps unconscious, basis of this practice is a desire for retribution-the vague feeling that no criminal flouting the lawful command of society's representative should be allowed to escape and thus avoid pumishment, even temporarily. However, the policeman is not the proper person to decide whether a criminal should be punislied. His function in this regard is to bring the suspect within the confines of the legal process, where he can come to trial. If a suspect escapes by fleeing arrest, the police can often appreliend him again later, given the ever-developing methods of police technology. ${ }^{81}$ Even if he were to escape altogether, as long as there is no reason to believe that he would pose a threat of death or serious bodily harm to others if not captured, it is more in society's interests to allow that escape than to assign the police an improper role which encourages them to visualize themselves as society's avengers rather than its protectors. Aside from being improper, this role is subject to abuse by both nervous and sadistic policemen, because they both tend to be unduly quick on the trigger. The harm

The other was Roy Banks, the last victim of the riot, who did not halt because he was deaf and dumb and therefore could not hear the order. A guardsman shot him as a suspected looter, but the manager of the lounge that Banks was supposed to have looted reported that he had boarded the place up on Monday night and that it would have been impossible for Banks to get in. Id. at cols. 5-6.

80 See note 70 supra and accompanying text.

81 Relevant in this regard is the oft repeated suggestion that police use unremovable dye or tranquilizer darts in their guns instead of deadly bullets, where the suspect threatens no deadly harm. E.g., Wills, The Second Civil War, EsQuIRE, March, 1968, at 81. 
caused by allowing the police to assume this role more than outweighs that caused by the escape of a few property offenders.

The amount of deadly force permitted a policeman effecting an arrest is more than that allowed to policemen or nonpolicemen in defense of property, which alone can never justify the use of deadly force, ${ }^{82}$ or in prevention of a felony, which can justify use of deadly force only if the potential offender is threatening the well being of another person. ${ }^{83}$ This disparity between the amount of force allowed to prevent the commission of a felony and that allowed to arrest a felon is only partially justified by the fact that some uncertainty is usually present when a felony is being prevented as to whether or not the person would have actually committed it. When an officer sees a theft occurring, it is criminal to shoot the thief if he is not threatening violence to another, even if the crime cannot be prevented in any other way. ${ }^{84}$ Yet when the theft is completed, if it is a felony, the officer is justified in shooting at the thief if it is the only way to prevent his escape. Since the thief's intent is evident in both instances, and his conduct does not involve physical danger to others in either mstance, the added increment of permissible force appears to be a punishment, either for his having actually completed the task, or for his having disregarded the policeman's authority. ${ }^{80}$

In addition, this use of deadly force raises possible due process problems, in that if the suspected felon dies, he will have been deprived of all the procedural gurantees of a fair trial. The Supreme Court has already held that a prisoner has a constitutional right to be tried by a legally

82 R. Perkins, Crmmanal Law 916-19 (1957). "In the absence of statutory authority the use of force intended or likely to cause death or great bodily injury is never authorized for the defense of property (as such)." Id. at 917. Of course, the statutes which allow the policemen to use deadly force against any fleeing felon circumvent this principle when they result in the police shooting at unarned looters, or anyone else reasonably suspected of having counmited a property crime which happens to be a felony.

83 See authorities cited note 73 sttpra.

84 R. Perkins, Crmminat Law 882-83 (1957).

85 See Comment, Justification for the Use of Force in the Crininal Law, 13 STیN. L. REv. 566, 581-84 (1961). The author says: "Justification should be regarded as a protective rather than a penal device. It should not concern itself with types of criminal activity, even those which merit the death penalty, but rather with the types of interests which might properly be defended to the extent of an immediate taking of life. . . .

... It seems doubtful ... whether the right to take a human life should be justified except when it is necessary for the protection of a competing luman interest." Id. at 583. With regard to the area of justification where a hounicide is committed to prevent the escape of a felon, the author says that the added increment of force may be an uncalculated quirk in the law or an attempt to use the practice as a punitive device. Either way he concludes: "The right to kill such a person [fleeing felon] should exist, as it does elsewhere in the law of justification, only when the criminal's escape would pose a threat to the physical safety of other persons...." Id. at 584 . 
constituted court of law, rather than by ordeal. ${ }^{86}$ Cases so holding have involved coercive action on the part of the police against a suspect after he is within their control, a factual situation obviously somewhat different from the one in which an officer shoots at a suspected felon in order to prevent his immediate escape. However, a statement by the Supreme Court in one of the cases is clearly relevant to the issue at hand:

Those who decide to take the law into their own hands and act as prosecutor, jury, judge, and executioner plainly act to deprive a prisoner of the trial which due process of law guarantees him. And such a purpose need not be expressed; it may at times be reasonably inferred from all the circumstances attendant on the act. ${ }^{87}$

If an officer kills a fleeing suspected felon, when he offers no serious threat to others and when there may be a good chance of apprehending him at a later time, that officer too is acting as "prosecutor, jury, judge, and executioner," in that he thereby deprives the suspect of any trial at all. ${ }^{88}$ Given the Supreme Court's recent increased interest in police practices and conduct, ${ }^{89}$ it is no longer unlikely that the protection of due process might eventually extend to this area of police use of deadly force to effect an arrest.

The same reasoning is generally applicable to the riot situation, but an additional word is in order, since so many contend that widespread use of guns is necessary to stop the rampant lawlessness inherent in a riot. $^{00}$ First, again the accuracy of the proposition is doubtful. When General Throckmorton took over command of the military operation in Detroit, he assigned the federal troops to the East Side of the city because the worst disturbances were occurring there. ${ }^{01}$ During the following five days the federal troops caused one death; the guardsmen on the West Side were involved in eleven. ${ }^{92}$ The federal paratroopers obeyed Throckmorton's order to unload their guns, keep their ammunition in their pockets, and fire only on orders, but the National Guard did not. ${ }^{93}$ Yet, though

86 E.g., Williams v. United States, 341 U.S. 97, 101-02 (1951) ; Screws v. United States, 325 U.S. 91, 107 (1945).

87 Screws v. United States, 325 U.S. 91, 106 (1945).

88 See Comment, Justification for the Use of Force in the Criminal Law, 13 Srav. L. Rev. 566, 584 (1961); P. TAppan, Crime, Justice and Correctron 186 (1960).

89 See, e.g., Miranda v. Arizona, 384 U.S. 436 (1966); Escobedo v. Tlinois 378 U.S. 478 (1964); Malloy v. Hogan 378 U.S. 1 (1964).

90 For a horrifyingly all-inclusive survey of the various weapons and techniques being contemplated to deal with future riots, see Wills, The Second Civil War, EsquTRE, March, 1968, at 71.

01 Final Report of Cyrus Vance, supra note 13, at 19.

02 Detroit Free Press, Sept. 3, 1967, § B, at 1, col. 1.

93 Hearings on National Guard, supra note 14, at 5881, 5892 . 
the cost in luman life was much greater, the National Guard was probably less efficient in pacifying the territory assigned to it, because it took longer to quiet the area..$^{94} \mathrm{~A}$ new element to be considered in future riots is that many new techniques are now emerging to aid in the nonviolent suppression of riots in the future. ${ }^{95}$

Second, the riot situation is similar to any other in that even at the height of the illegal activity, stopping the riot is not the only proper goal. Given the already existing problems between the Negro community and law enforcement authorities, ${ }^{06}$ the latter must take the community relations aspect of their activities into account even when they are trying to suppress a riot. The Task Force Report on the police, submitted by the President's Commission on Law Enforcement and Administration of

${ }^{94}$ See N.X. Times, July 27, 1967, at 18, col. 1.

95 Wall Street Journal, Aug. 10, 1967, at 1, col. 4, reports the development of new riot control methods, such as "mstant banana peel," a chemical powder which will make the streets so slippery that no one will be able to enter the area, "instant shock," a system for transmitting an electric slock through rioters by use of water from a fire bose or portable back pack unit, and "mace," a combination of tear gas and other disabling chemicals that can be squirted from an aerosol can.

The author of another article describes these various plans in this way: "I read, in the unearthly prose of the Institute for Defense Analyses, about new weapons, all supposedly non-lethal, but devastating to the caught imagination. Foam your rioters, pepper them, festoon them in long swaths of chewing gum; mark them with invisible dyes, with odors undetectable except by dogs or instruments; snow them up inside drifts of plastic confetti, prick them with tranquilizers; rinse them down with electric sluices; stay them with hoses." Wills, The Second Civil War, Esquine, March, 1968, at 71, 81.

Later in the article, he gives even more examples of developments in "non-lethal" weapons, such as barbed wire "concertinas" used to channel the run of cattle now being bought by police for barricading streets, and sound waves that make men loose their bowels or other "curdling" sounds that drive mèn from their vicinity. Id. at 140. Some of these "non-lethal" weapons may be nore appropriaté to concentration camps than American cities, and certamly the police should consider the moral implications of all of them, as well as their practical efficiency.

At the same time, deadly weapons are being developed in droves. A few examples include a 12-gauge shotgun that can fire off five rounds in rapid succession while lying in the crook of one arm and a one-hand machine gun that can fire 270 rounds of $9-\mathrm{mm}$. bullets in one minute. Wall St. J., supra, at 8 , col. 4. For a more comprehensive list and descriptions of the various types of heavy equipment being considered, see Wills, sutprd, at 71 .

President Jobnson's National Advisory Comm'n on Civil Disorders had this to say about the use of "mass destruction" weapons by city police departments: "The Commission believes that equipping civil police with automatic rifles, machine guns, and other weapons of massive and indiscriminate lethality is not warranted by the evidence. . . . We should not attempt to convert our police into combat troops equipped for urban warfare.

... Great harm is likely to result from the use of military weapons of mass destruction by police forces which lack the command and control and firearms discipline of military units. Improper action could destroy the concept of civilian police as a public service agency dependent for effective operations on community cooperation and support." RePoti of THE National Advisory Comanssion on Civil Disoroers 492 (Bantam 1968).

${ }^{96}$ See text accompanying notes $135-44$ infra. 
Justice, ${ }^{07}$ takes note of the fact that if the police do not consider this other factor the deterrence factor itself may be considerably weakened:

Once a disturbance or riot is in progress, of course, the dominant consideration must be to end it. However, even then, it is extremely important that the means used be weighed for their effect on policecommunity relations. This is essential since actions which stir up antagonism in turn may prolong the riot and increase the hikelihood of future ones. Alternative methods of equal, or virtually equal, effectiveness may be available for controlling the riot which will cause less serious damage to police-community relations. ${ }^{98}$

The experience of the federal troops in Detroit would indicate that indeed there are "alternative methods of equal, or virtually equal, effectiveness" available.

Third, in the use of deadly force where not necessary to protect people from serious bodily harm or death during the riot situation, the various law enforcement authorities again perform an inappropriate punitive function, much harsher than the one which the courts actually discharge. Of the 2,761 adults booked on felony charges in the Watts riot of 1965 , the courts convicted only fifty-seven percent; of the 2,038 adults convicted of any crime the courts gave only thirty-six percent jail sentences; they sent a mere seven to the state prison. ${ }^{99}$ The courts in Detroit at present seem to be following the same lemient pattern. ${ }^{100}$

In summary, our legal system claims to value human life above property interests, and consistently with that aim: (1) Does not allow anyone to use deadly force solely for the defense of his property; (2) does not allow a police officer to use deadly force to arrest a person who has committed a misdemeanor; and (3) does not allow anyone to use deadly force to prevent a crime unless that crime threatens the life or physical safety of another. Yet the policeman makes broad use of his authority to use deadly force against a fleeing felon, irrespective of the suspect's danger to others, both in and out of the riot situation. ${ }^{101}$ This practice, in effect,

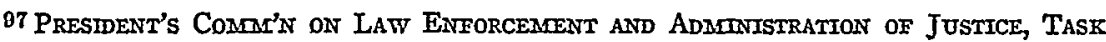
Force Report: The PoITCe (1967) [hereinafter cited as TASK Force Report on the POLICE].

08 Id, at 193 .

00 U.S. NEWS \& WORID REPORT, Aug. 28, 1967, at 52.

$100 \mathrm{Id}$.

101 TASK Force RePort on THE POIICE, supra note 97 , at 189, mentions a study by an ACLU affiliate in a medium-sized city that found that police officers fired guns more than 300 times during a two-year period, and over one-third of these incidents were during automobile chases involving juveniles.

The same source reports a study conducted by Michigan State University which estimated an average of 240 per year fatally injured by police during the period 1950-60 in the United States, and concluded that officers often use their guns indiscriminately largely because of an overemphasis of the danger involved in police work. Id. 
means that many people have paid with their lives for mere property crimes. Although these deaths may be legally justifiable, "[O]ne is still left with a feeling that the thief who takes five dollars worth of goods from a grocery store slelf and runs ought not to be required to pay with liis life."102

For all these reasons, changes are necessary in the general law governing the use of deadly force and in the riot laws which justify any homicide committed in the course of suppressing a riot or domestic insurrection. These changes should be applicable to all law enforcement agencies which are active in the riot situation.

\section{B. Specific Proposals}

The first requirement for any improved statute is that it specifically state that a policeman cannot use deadly force to prevent the escape of anyone, whether a suspected felon or misdemeanant, unless he reasonably believes that the person trying to escape will pose a threat of deatl or serious bodily liarm to others if the police do not immediately apprehend him. Statutes which would himit the right to use deadly force to situations where the officer reasonably believes that the suspect has committed a "dangerous" felony, ${ }^{103}$ or even a felony involving the use or threatened use of deadly force, ${ }^{104}$ would not be fully adequate in this regard, although

102 Detroit Free Press, Sept. 3, 1967, § B, at 1, col. 2.

103 Suggestions that this is the principle that should govern can be found in Storey v. State, 71 Ala. 329, 339 (1882); State v. Sorrentino, 31 Wyo. 129, 137-38, 224 P. 420, 422 (1924); R. Perkirs, Crminal Law 882-83 (1957). Perkins specifically makes the point that if the use of deadly force is limited to so-called dangerous felonies, "[a] felony otherwise entitled to milder classification becomes a dangerous felony if the inanner of its commission creates the likelihood of death or serious bodily injury; whereas one of the typically dangerous felony remains in this category regardless of the circumstances of the particular offense." $I d$. at 875-76. There is no reason why the "typically dangerous felony" cannot also shift into another category if the circumstances of its commission indicate that it has somehow been counmitted in a way not involving the likelihood of death or serious bodily injury.

104 There have been three statutes drafted along these lines, N.X. PEN. LAw $\$ 35.30$ (McKinney 1967); MODEL PENAI CODE $\$ 3.07$ (Proposed Official Draft 1962); A.B. 2357, Cal. 1967 Sess. (a bill to amend CAL. PEN. CODE $\$ 196$ (West 1955), now in interim committee study). All these statutes, one of which is now the law in New York, abolish the rigid distinction between felonies and misdemeanors, and substitute the principle that officers can use deadly force only when they reasonably believe that the felony which the suspcct committed involved the use or threatened use of deadly force, or that there is a substantial risk that the suspect will cause death or serious bodily harm if his apprehension is delayed. Moder Penal Code \& 3.07(2)(b)(iv)(1), (2) (Proposed official Draft 1962); A.B. 2357, $\S 196$ (3) (c) (i), (ii), Cal. 1967 Sess. The New York statute substitutes two provisions for the last category: First, if the suspect is trying to escape by use of a deadly weapon; and second, if he otherwise indicates that he is likely to cause death or serious bodily injury unless he is apprehended without delay. N.Y. PEN. LAw § 35.30(2) (b) (ii), (iii) (McKinley 1967). These two taken together have the same effect as the one provision that the use of deadly 
they would be an improvement over the present state of the law. It is true that in the vast majority of cases a policeman would have grounds for a reasonable belief that a person he suspects of having committed a dangerous felony, or one involving the use or threatened use of deadly force, poses a threat of plyysical harm to others. But a statute with either of these requirements would still have the wrong empliasis. By its terms it should inform the policeman of his solely protective role. If the rare situation were to occur in which a person had used or threatened to use deadly force to commit a felony, but at present he did not appear to be a serious threat to others-for instance, where the police had disarmed him and it appeared that they could apprehend him before he could get another gun and injure someone- the policeman should not have the right to use deadly force. ${ }^{105}$ The statutes should make it perfectly clear that the policeman's riglit to use deadly force is only a device for protecting the lives and safety of others. The officer should examine the circumstances of eacl situation in order to decide whether or not to use deadly force to prevent a suspect's escape. He should not fit the situation automatically into a simple category. A former New York City Police Commissioner made this statement regarding the present law in New York goverming police use of deadly force: "There are still too many areas making it necessary for the policeman in the street to wrestle in his mind before

force is justified if the officer reasonably believes there is a substantial risk that the suspect will cause death or serious bodily harm if his apprehension is delayed.

In addition to the two types of proposed statutes in the text, Professor Mikell has suggested limiting the policeman's use of deadly force to situations where he reasonably believes that the suspect has committed a capital crime. Part of his argument is quoted in J. MrceAer

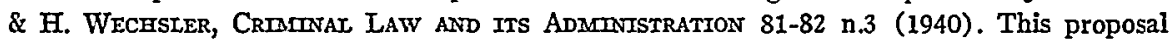
seems to say that the policeman can punish, but not disproportionately by meting out a punishnent much greater than the one the state may impose. Therefore he can only risk killing a suspect where the state may kill that suspect later in any case. Unless the suspect would be a serious threat to others if not immediately apprehended, the policeman would be performing a punitive function. Yet the policeman could never use deadly force in states which have abolished capital punishment, or in cases where he suspects a noncapital crime, unless on the grounds of self-defense or defense of others, so the proposal would limit his flexibihty in performing his protective function. "[Mikell's] suggestion recognizes the injustice of allowing the actor to impose a greater penalty than might be imposed by a jury. But this proposal assumes that he should be allowed to impose as great a penalty as a jury might impose, which seens a highly dubious assumption in light of the jury's unique function in determining criminal liability and penalties." Comment, Justification for the Use of Force in the Criminal Law, 13 Stan. L. REv. 566, 582 (1961).

105 This statement demonstrates the main difference between the proposed standard and N.Y. PeN. LAw $\$ 35.30$ (McKinney 1967); ModeL Penal Code $\$ 3.07$ (Proposed Official Draft 1962); and A.B. 2357, Cal. 1967 Sess. See note 104 supra. Under all three of those statutes the officer could still use deadly force against the fleemg felon because he had committed a felony which in turn involved the use or threatened use of deadly force. Under the standard proposed in this Comment, the officer could use deadly force only when the fleeing felon posed a future danger to others; in other words, only on the second ground provided for police use of deadly force in these three statutes. 
taking action." 106 When else should a man "wrestle in his mind" if not when human life is at stake? This remark exemplifies the attitude which the police must learn to avoid when such important action is involved.

The second requirement for any new statute is a provision msisting that the officer reasonably beheve that the force employed creates no substantial risk of injury to innocent persons. ${ }^{107}$ No statutes presently in effect have been found which mention this consideration, although some courts have taken it into account. ${ }^{108}$ But if the officer's function in the use of deadly force is to protect the hives and safety of others, then it is obvious that the law should require him to consider whether there are any bystanders in the area whom his action might endanger. The lack of substantial risk to innocent persons should be a necessary prerequisite to use of deadly force to effect an arrest, though at first glance this may appear too restrictive. In this regard, it is essential to remember that the officer may also use deadly force under the general grounds of self-defense or defense of others. ${ }^{109}$ The purpose of the additional power with respect to arrests should be only to allow use of deadly force when a delay in apprehension will cause a threat to the safety of others not yet so evident that the law would pernit use of deadly force on the ground of defense of another. By definition, this threat is not yet certain, however, and therefore does not warrant substantial risk of death or serious bodily harm to

106 N.Y. Times, Feb. 5, 1968, at 46, col. 7. At this time, it appears that N.Y. PEN. LAw $\$ 35.30$ (McKinney 1967) will soon be repealed. Both houses of the New York Legislature have just passed a bill which will replace it when it is signed by the Governor. N.Y. Times, March 6, 1968, at 1, col. 7. Under this measure a policeman could shoot to kill a fleeing person if he reasonably believes the person has cominitted a felony and was armed with a firearm or deadly weapon, even though the person did not use, or try to use, the weapon, or indeed, use any force at all. Id. at 47, cols. 2-3. The bill also contains a "no-sock" provision-making it a felony for a person physically to resist arrest by a policeman, even if the arrest were illegal, id. at 1, col. 7 , and a provision saying that a policeman or private citizen can sloot at a suspected arsonist, even if the suspect was not trespassing on the property involved, id. at 47, col. 2. A third additional provision in it would allow the resident of an apartment or lrome to use deadly force against an intruder if the resident reasonably believes that such force is necessary to prevent or terminate a burglary or intrusion, regardless of whether the intruder appears ready to use force. S.F. Chronicle, March 6, 1968, at 13, col. 2.

This bill not only removes the leart of the most progressive law in the country regarding the policeman's right to use deadly force, but also, by the dangerous rights which it accords to the private citizen, will encourage extensive arming and vigilante action on the part of the white population in New York. It reflects the mood of hysteria which today characterizes the response of many politicians and citizens to the riots. So long as this hysteria exists, hittle attenpt will be inade to attack the deep causes of the riots or to lessen the hostility which exists between residents of the Northern ghettos and members of the white community, or between Northern Negroes and the poliee.

107 This provision is found in MODEL PENAI CODE $\$ 3.07$ (2) (b) (iii), (Proposed Official Draft 1962), and in A.B. 2357, $\$ 196(3)$ (b), Cal. 1967 Ses:s.

108 See, e.g., cases cited note 40 supra.

109 See text accompanying notes 20-22 supra. 
innocent bystanders. This risk often accompanies the use of deadly force against a suspected felon, because the police action usually occurs in a crowded urban area. The risk is particularly prevalent in the riot situation because at that time the streets are generally inore crowded than ever with police, firemen, rioters, and curious onlookers. If this requirement that there be no substantial risk to innocent persons is not insisted upon, the policeman will often create a risk at least as serious as the one which he is supposed to prevent.

A third necessary requirement is that the policeman make kniown his purpose to arrest, or believe that the suspect otherwise knows it, or cannot be reasonably made to know it before he uses any kind of force to effect an arrest. ${ }^{110}$ Existing statutes do not generally imclude this requirement. It should be in all of them, at least where deadly force would be permissible. The law should insist that a policeman try his best to make his purpose known before using force, in order to forestall attempts at resistance or escape.

A statute with these three requirements would allow an officer enough flexibility in his use of deadly force to enable him to handle any situation, including a riot. The function of the law enforcement authorities' use of deadly force in a riot should still be to protect citizens from death or serious bodily harm, though methods short of deadly force should be used, of course, to protect the property interests which the riot threatens. ${ }^{111}$ For this reason, all the statutes which widen the category of justifiable homicide for law enforcement authorities in the riot situation should be eliminated. At least the courts should construe those which use language like "law fully suppressing a riot" to mean that the general statutes governing use of deadly force apply, and the scope of "lawful" use of deadly force is no wider than in any other situation.

The riot situation, however, does merit special attention in that more than one law enforcement authority is present, and the legal standards that govern the actions of both the National Guard and the federal troops are unclear. ${ }^{113}$ The issue of the proper response to the riots is very sensitive, and it is at the times when the nation feels that it is facing a threat from within that the constitutional and procedural guarantees of the group which it feels to be threatening are most in danger. Since the call throughout nost of the country is for increased force and repression to put down the riots, ${ }^{114}$ it is highly unreahistic to expect Congress to pass a

110 Moder Penal Code $\$ 3.07$ (2) (a) (i) (Proposed Official Draft 1962) includes this provision.

111 See text accompanying notes 90-102 supra.

112 E.g., Cal. Pen. Code $§ 197$ (4) (West 1955); Mich. Stat. ANN. § 28.795 (1954).

113 See text accompanying notes 44-68 supra.

114 See, e.g., Wills, The Second Civil War, EsQuIRE, March, 1968, at 71. 
Federal Riot Act implementing the above recommendations which favor restraint of the policeman's use of deadly force, although there is little doubt that it could do so by exercise of its powers under the fourteenth amendment ${ }^{115}$ or the commerce clause. ${ }^{110}$ It is exactly in these situations of internal crisis that the courts should be most vigilant in their role of protecting individual rights against majority opinion.

To this end the Supreme Court should apply federal law to any cases which involve the actions of federal troops, federalized guardsmen, or their military commanders ${ }^{117}$ and develop a uniform federal standard implementing these recommendations. The most typical way in which a case would arise would be a battery action brought by the victim against the soldier or guardsman. The defendant would interpose his federal authority as a defense, thus raising a question of federal law. After the state or federal trial court passed on this defense, the United States Supreme Court would have jurisdiction to review the trial court's determination of the issue. ${ }^{118}$ So long as some order or military regulation in the chain of authority from the statute authorizing the President to commit military forces to quell internal civil disturbances to the order received from the defendant's direct superior speaks in terms of reasonable or necessary force, the Court can, by construction, implement the proposed standards.

With regard to the unfederalized Guard, the applicability of federal law is less clear. As stated above, ${ }^{119}$ Maryland $v$. United States ${ }^{120}$ is an indication that state law, rather than federal, applies to the actions of unfederalized guardsmen. However, it is possible that future interpretations of Maryland will limit it to its facts, which involve a suit against the federal government under the Federal Tort Claims Act, ${ }^{121}$ rather than extending it to situations concerning a guardsman's personal liability for his acts during a riot. The key factor in distingushing Maryland would be the need for a uniform federal standard in this area. ${ }^{122}$ This uniformity is desirable, because any military units called in to quell domestic disturbances face similar problems since their sole task is to restore the peace and turn over detained persons to the local authorities, rather than booking and

115 See Katzenbach v. Morgan, 384 U.S. 641 (1966); United States v. Guest, 383 U.S. 745 (1966); Comment, Fourteenth Amendment Enforcement and Congressional Power to Abolish the States, 55 CALIF. L. Rev. 193 (1967).

110 See Katzenbach v. McClung, 379 U.S. 294 (1964); FIeart of Atlanta Motel, Inc. v. United States, 379 U.S. 241 (1964).

117 See text accompanying notes 47-53, 63-64 supra.

118 See Martin v. Hunter's Lessee, 14 U.S. (1 Wheat.) 304 (1816).

119 See text following note 62 supra.

120381 U.S. 41 (1965).

12128 U.S.C. $\S \S 1291,1346,1402,1504,2110,2401-02,2411,2412,2671-80$ (1964).

122 See text accompanying notes 48-52 supra. 
jailing them on their own authority. Also, this intrusion of the military has an effect on the United States' image at home and abroad, thus giving the federal government a strong interest in having the disturbances quelled by the application of a uniform policy designed to halt the disorder with a minimum of force. Since the National Guard, even in its unfederalized state, possesses a quasi-federal character in that its members are equipped, recruited and paid in accord with federal statutes, ${ }^{123}$ questions concerning it are of a sufficiently federal character to permit application of federal law.

A clear definition of the purely protective function to be served by the military forces called in to quell a riot, through the evolution of a judicial standard where federal law is applicable, would serve two important and constructive purposes: (1) Insure uniformity, at least among the military forces, in applying the deadly force policy most likely to win the sympathy of the law abiding sectors of the Negro community and avoid laying part of the groundwork for the next riot, because it is a policy which allows for effectively quelling a riot at minimum cost to human life and safety; and (2) encourage uniformity in the state law regarding use of deadly force, in both riot and nonriot situations, by its example.

The best way to perform its function as protector of minority riglits, however, would be for the Supreme Court to extend the protection of the due process clause of the fourteenth amendment by prohibiting police use of deadly force except in situations where the suspect poses a threat of serious plysical harm to others. ${ }^{124}$ This step would also be the most desirable because its effect would extend beyond the military authorities to the local police agencies, and beyond the riot situation to everyday life on the streets of American cities.

IV

THE PROBLEM ON THE ADMINISTRATIVE LEVEL

Changes confined to the statutory level are never enough to ameliorate an undesirable situation concerning law enforcement practices. In the first place, a legislative standard is necessarily somewhat vague and general since its terms must be broad enough to encompass all situations which may arise in the area the statute seeks to regulate. A clear, complete administrative policy offers much more specific guidelines to the individual officer for the varied situations which he will have to handle. ${ }^{125}$

123 See text accompanying notes 56-58 supra.

124 See text accompanying notes 86-89 supra.

125 "However great the legislative contribution may be, experience demonstrates that legislatures can never deal specifically with the wide variety of social and behavioral problems which confront police. . . . The 'administrative process' and administrative flexibility ... are as necessary and as appropriate with respect to the regulation of deviant social 
In the second place, an obvious drawback to the statutory standard when it exists alone is that the judicial review which it creates deals only with criminal and civil actions brought to court. There are a number of obstacles to either type of case ever reaching the courtroom in the field of statutory regulation of the police. The most serious problem with regard to a criminal action is the reluctance both of the district attorney to prosecute actions against members of a police department with which he must work in daily close cooperation, and of the police to testify against each other. ${ }^{128}$ Other problems are the frequent lack of the requisite criminal intent in the policeman's misconduct and, in the courtroom, the unwillingness of juries to believe the word of the average citizen when a policennan contradicts him. ${ }^{127}$

behavior as they are with respect to other governmental regulatory activity." TASK FORCE REPORT ON THE PoITCE, supra note 97, at 18.

Another reason why a legal standard is not sufficient in the absence of able administrative leadership is because the policeman usually sees a legal standard which limits his activities as an obstruction to be overcome by manipulation of the facts. As one author, speaking of the exclusionary rule specifically, has said:

The policeman typically feels that courts hatve provided insufficiently clear standards for routine decisions. Where the policeman perceives the line between legality and illegality as hazy, he usually handles the situation in the interest justifying a contention of legality, irrespective of the actual circumstances. He therefore operates as one whose aim is to legitimize the evidence pertaining to the case, rather than as a jurist whose goal is to analyze the sufficiency of the evidence based on case law.

... His "compliance," however, may take the form of post hoc manipulation of the facts rather than before-the-fact behavior. Again, this generalization does not apply in all cases. Where the policeman feels capable of literal compliance . . . he does comply. But when he sees the case law as a hindrance to his primary task of apprehending criminals, he usually attempts to construct the appearance of compliance, rather than allow the offender to escape apprehension.

J. SkOLNICK, Justice Withodt TrtaI 214-15 (1967). Obviously, the pohice commissioner and others of a high rank within the police department are better able to control this kind of "fudging" than the courts, providing they choose to do so.

126 See White v. Towers, 37 Cal. 2d 727, 737, 235 P.2d 209, 215-16 (1951) (dissenting opinion); Foote, Tort Remedies for Police Violations of Individual Rights, 39 MrNN. L. REV. 493 (1955).

The Governor of New Jersey's Select Commission on Civil Disorders quotes this language to illustrate the problem: "Agencies empowered to oversee local law enforcement, such as the F.B.I., are reluctant to move against the same men with whom they work and on whom they depend for evidence for successful federal prosecutions. In counties where tho district attorney's office is empowered to conduct its own investigations, prosecutions against erring law enforcement officers are no greater in number for the same reason: the district attorney depends on the local police departments for evidence sufficient to convict." REPORT FOR ACTION, supra note 12, at 37. This problem often exists with regard to the bench too. In Newark's Municipal Court the Chief Magistrate has refused to liear any cases dealing with complaints against the police, saying, "I've instructed any court not to take complaints against police officers. We're too busy." $I d$.

127 According to Arthur Caldwell, a longtime lawyer in the Civil Rights Section of the Justice Department, the chances of winning police brutality cases are poor. He ex- 
Although there are possible bases for tort recovery against police action in a riot situation, both under the present state of the law ${ }^{128}$ and under the recommended changes, civil actions also present serious problems. It is difficult to obtain proof without the cooperation of the police. The police department tends to protect its members against civil suit, even to the extent of not instituting disciplinary proceedings for fear of prejudicing the officer's case in the trial. ${ }^{129}$ An individual officer often does not have substantial financial resources from which to satisfy a judgment, unless his department requires or provides liability insurance, and in many places the principle of municipal immunity still operates. ${ }^{130}$ In addi-

plained: "Police brutality cases are the most difficult kind of criminal cases. Evidence is liard to come by even when the arrestee is in the hospital. No one lias seen anything. Unless the case is really bloody, the jury will assume it wasn't serious enough to warrant punishing the officer." REPORT FOR ACTION, supra note 12, at 36. The report adds: "One of the major problems in proving these charges is that the situation eventually boils down to a citizen's word against that of a policeman." Id.

128 It might be feasible, for example, to sue a policeman, guardsman, or federal soldier for negligence or recklessness in performing the tasks assigned to him. A particularly good case would be where a guardsman had failed to obey the orders concerning use of deadly force, and as a consequence had injured or killed someone.

Another possible basis for recovery, where the principle of sovereign immunity is no longer in effect, would be that of negligent training in a suit brougbt against the city, if it concerned a local policeman, or against the state if it concerned a guardsman. See Nishan v. Godsey, 166 F. Supp. 6 (E.D. Tenn. 1958) ; Peer v. City of Newark, 71 N.J. Super. 12, 176 A.2d 249 (1961); Meistinsky v. City of New York, 285 App. Div. 1153, 140 N.Y.S.2d 212 (1955), aff'd, 309 N.Y. 998, 132 N.E.2d 900 (1956).

A third argument applicable to many cases would be that the law enforcement officer, whether a policeman, guardsman, or federal soldier, was negligent in creating an unnecessary risk to innocent bystanders, even thougl justified in his use of deadly force under the circumstances. See, e.g., cases cited in note 40 supra.

On the basis of the due process problems of allowing a law enforcement authority to use deadly force when there is no threat of death or serious bodily harm to other persons, there might be a cause of action under 42 U.S.C. \$ 1983 (1964): "Every person who under color of any statute, ordinance, regulation, custom, or usage, of any State or Territory, subjects, or causes to be subjected, any citizen of the United States or other person within the jurisdiction thereof to the deprivation of any rights, privileges, or immunities secured by the Constitution and laws, shall be liable to the party injured in an action at law, suit in equity, or other proceeding for redress." The United States Supreme Court has beld that, since the remedy provided by this statute is civil rather than criminal, no element of specific intent is required for recovery. Monroe v. Pape, 365 U.S. 167, 187 (1961). See generally Greenstone, Liability of Police Officers for Misuse of their Weapons, 16 CEEv.-MaR. L. REV. 397 (1967).

120 TASK FORCE REPORT ON TERE PoITCE, supra note 97, at 31.

130 "If court created sovereign immunity once served a valid need and purpose, that need and purpose are historical now, and the new needs of the individual citizen vis-a-vis lis state are disserved by the archaic doctrime." Greenstone, supra note 128, at 399.

As an example of how much force the doctrime of sovereign immunity still possesses today, see the opinion in Monroe v. Pape, $365^{\circ}$ U.S. 167 (1961), which stated that Congress did not intend to bring nunicipal corporations within the ambit of 42 U.S.C. $\$ 1983$, and precluded a suit against a city on this basis. Id. at 187. Abolition of sovereign immunity is also one of the main recommendations in Foote, suppa note 126, at 514. 
tion, juries are unlikely to grant a verdict to a "criminal" type. Finally, the average citizen, particularly in the lower socio-economic levels where police misconduct is most prevalent, is not apt to take the initiative and bear the expense necessary to bring a civil suit to court. In all, only a very small number of the actual instances of police misconduct ever reach the courtroom, and even fewer end with a verdict against tlie policeman. ${ }^{131}$

The likelihood of a citizen successfully asserting his rights in a situation involving use of unnecessary force to effect an arrest is even slighter than in other circumstances. It is very difficult for the victim of a police assault to prove that there was no ground for an arrest, that the officer did not place him under arrest, that he did not resist the arrest, or that the force used was unreasonable, particularly since the police can charge anyone they have mistreated with resisting arrest or assaulting an officer in order to protect themselves. ${ }^{132}$ Thus, in addition to all the other problems, the mistreated person risks having to face prosecution for added serious offenses if he dares to bring an action against an officer for unlawful use of force to effect an arrest. ${ }^{133}$

All the problems regarding civil and criminal actions are heightened when police misconduct occurs during a riot in the Negro ghetto. ${ }^{134}$ The situation involves confusion, panic, and uncertainty on all sides. The law

131 As an example of this, in Newark, police department statistics for the last two years show that twenty-one complaints of police brutality were brought to the Inspection Office of the Police Department in 1966, and nine in 1967. But in none of these cases was a policeman brought up on charges for excessive use of force against a citizen while on duty. REPORT FOR ACTION, supra note 12, at 35-36.

Also, the fact that the Clief Magistrate of Newark's Municipal Court has refused to lear cases on police brutality obviously tends to keep the cases from reaching the courtroom. See note 117 supra. For a full discussion by the Commission of the Newark Negro community's frustration over lack of redress for mistreatment by police see REPORT FOR AcTion, supra note 12 , at 32-37.

132 See P. TAPpan, Crman, Justice and Correction 285 (1960).

133 See id. The hint that the police will cause a felony conviction if charges are brought against them is not so fantastic as it seems when one remembers that in the San Francisco courts a defendant is usually given a waiver of any rights lie may have against the police to sign before his charges are dropped. Telephone conversation with an attorncy of the San Francisco pubhe defender's office, March 20, 1968. According to a 1962 report, in Washington, D.C. the police department filed charges of bringing false reports against the police against $40 \%$ of the people who attempted to complain of police misconduct or abuse. National Center on Police and Community Relations and School of Police Administration and Public Safety of Michigan State University, A National Survey of Police and Community Relations 204 (1967) (mimeo submitted to the President's Commission on Law Enforcennent and Administration of Justice) [hereinafter cited as Survey of Police-Community Relations].

${ }_{134}$ As far as the author knows there has not yet been an opinion written on any action, criminal or civil, arising from pohce activity during a riot of the recent type, though there have been some preliminary actions brought. For a description of the atmosphere that prevailed at the inquests held to investigate the deaths that occurred during the Watts riot, see R. Conot, Rrvers of BLood, Years of Darkness 396-409 (1967). This is one of the best and most thorough analyses of any of the recent riots that has yot been written. 
enforcement authorities are working under very difficult circumstances and will be immediately hostile to anyone who challenges their authority, whether on the streets or in the courtroom. The district attorney's office is flooded with cases against the rioters and will not be sympathetic toward possible cases on behalf of them and against the police. In general, public reaction is highly unfavorable toward all people involved in the riots, including onlookers, and much more disposed to authorize harsher police action than to criticize an officer's misconduct in quelling the riot. For this reason there is no substantial public pressure on the district attorney to institute criminal proceedings, and it is extremely difficult to obtain an unbiased jury anywhere in the country.

In sum, the legal changes recommended above simply are not enough to solve the problem. New policies regarding the use of deadly force in the riot situation must be initiated within the internal levels of the police departments and the state militias. The federal troops' policy in Detroit was commendable in that it effectively restrained the unnecessary use of deadly force. Therefore, in making recommendations for change on the internal administrative level, that policy will be used for comparative purposes.

\section{A. Internal Administrative Attitudes}

\section{Local Police Agencies}

The attitude of police and residents of the Northern ghettos toward one another can be summed up in two words-mutual hostility. ${ }^{135}$ The Negroes in the ghetto view the police as representatives of an arbitrary type of authority wlio are inadequate in the performance of their jobs on three main levels: (1) They do not properly protect the Negro neighborhoods from crime; (2) They employ a variety of discriminatory practices against Negroes in general; and (3) They discriminate against Negroes in police personnel practices such as hiring and pronoting. ${ }^{136}$

135 "Indeed, it is the pressure exerted by these [mutual] hostilities which makes it so very important that top policy-making be in civilian control and that mayors and civilian police commissioners exercise in fact the control which the law grants to them." Edwards, Order and Civil Liberties: A Complex Role for the Police, 64 MrcH. L. REv. 47, 56 (1965) (author is former Police Commissioner of Detroit).

136 For a discussion of all these elements, see Survey of Police-Community Relations, supra note 133, at, 14-19. Regarding the problem of improper police protection specifically, see REPORT OF THE NATIONAT ADVISORY COMNMISSION ON CIVIL DISORDERs 307-09 (Bantam 1968).

In the Newark police department, which has an authorized quota of 1,512 men, Report For ACTION, supra note 12, at 22, there are 145 Negroes and one Puerto Rican in the Department, id. at 24 . This is to serve a population that is at least $52 \%$ Negro and about $10 \%$ Spanish-speaking. Of the Negroes who are on the force, all but nine hold the lowest rank. Id. Given these statistics as an example, it is easy to see why Negroes might reasonably conclude that the police discriminate in liring and promotion. For further statistics on the 
There is a vast difference between the attitudes of the white and Negro communities toward their respective police departments. Members of white neighborhoods generally trust the police and have only relatively minor complaints, while most residents of the ghettos distrust and dislike them. ${ }^{137}$ This disparity is important as an indication of the Negro's basic lack of faith in the legal system which governs them, and especially in that system's representatives with whom they come into contact on the day-to-day level..$^{138}$ Since white people's expectations are so different, it is not surprising that the white community in general is not overly sympathetic to what they see as constant harping by the Negroes on charges of police brutality.

The Negro glettos have clearly manifested their lostility toward the local police in all the riots since 1965. First, almost all of them have been set off by police incidents. ${ }^{139} \mathrm{It}$ is clear that even a minor altercation involving an officer and a Negro in a ghetto neighborhood can result in a tense, explosive situation within minutes in any of the large Northern cities. Second, the police are a major target during the riot itself-snipers'

number of Negroes on city police forces and what positions they hold, see REPORT ON THE Natronal Advisory Comanusston on Civin Disorders 315-16 (Bantam 1968).

137 Survey of Police-Community Relations, supra note 133, at 13, 20-21. A recent survey indicated that $85 \%$ of the Negroes who responded felt that the police discriminated in a variety of ways. Id. at 15-16. For a percentage breakdown in the responses of whites and Negroes recently polled on the question: "On the basis of your knowledge of American police departments, how does your police department compare with others?" see id. at 11 (table). The authors of this survey conclude that the vast najority of whites are either apathetic toward the entire police problem or support the police, and that most of their complaints are in the area of service and technical competence. Id. at 20. The authors also noted that: "[T]he field survey did discover elements of the 'backlash' syndrome. While by no means in the najority, certain individuals expressed dismay and fear as a result of whiat they classified as 'the too rapid pace of the civil rights revolution' or in more cases they indicated serious concern over the spectre of riots. In both instances, although nore often in the latter, their support seeined in terms of the protection which the police provide against riotous behavior on the part of minority groups, particularly Negroes." Id. at 20-21.

For the results of other studies which indicate the same disparity in attitudes toward the police, see Report of the Nationat Advisory Comanasston on Crvar Disorders 302 (Bantain 1968).

138 In contrast, the whites in general have faith in the legal systenl, and although they usually do not see their police departments as being perfect, they visualize steady improvement. Survey of Police-Comununity Relations, supra note 133, at 42.

139 PrEsDDENT'S COMOM'N ON LAW ENFORCEMENT AND ADMINISTRATTON OF JUSTICE, TASK Force Report: CrDME and ITS IMTPACT-AN Assessment 116 (1967) [hereinafter cited as CRIME AND ITS IJIPACT]. "We have cited deep liostility between police and ghetto comnuunities as a primary cause of the disorders surveyed by the Commission. In Newark, in Detroit, in Watts, in Harlem-in parctically every city that las experienced racial disruption since the summer of 1964-abrasive relationships between police and Negroes and other minority groups have been a major source of grievance, tension and, ultimately, disorder." Report of the National Advisory Conarission on Civil Disorders 299 (Bantam 1968). 
fire, bottles and other objects, epithets and insults, all are directed at the police and later at any other law enforcement authorities brought in. ${ }^{140}$

The general attitude of the police toward Negroes in the ghettos is also one of hostility and distrust, expressed in their daily work in these neighborhoods. They have a tendency to think of most Negroes as "criminal" types, ${ }^{141}$ to disbelieve their complaints about police misconduct, ${ }^{142}$ and to fail to understand and appreciate the cultural differences of minority groups. ${ }^{143}$ Worst of all, they are usually racially prejudiced. ${ }^{144}$

140 CRAME AND ITS IMTPACT, supra note 139, at 121.

141 "Although local police forces generally regard themselves as public servants with the responsibility of maintaining law and order, they tend to minimize this attitude when they are patrolling areas that are heavily populated with Negro citizens. There they tend to view each person on the street as a potential criminal or enemy, and all too often that attitude is reciprocated. Indeed, hostility hetween the Negro communities in our larger cities and the police departments is the major problem in law enforcement in this decade." Edwards, supra note 135, at 54-55.

142 The liead of the Federal Bureau of Investigation; J. Edgar Hoover, believes that charges of police brutality are simply a part of the nationwide Communist conspiracy with which he has been so concerned for most of lis career: "[F]or years it has been Communist policy to charge 'police brutality' in a calculated campaign to discredit law enforcement and to accentuate racial issues. The riots and disorders of the past 3 years clearly highlight the success of this Communist smear campaign in popularizing the cry of 'police brutality' to the point where it lias been accepted by many individuals having no affiliation with or sympathy for the Communist movement." Excerpts from the Testimony of John Edgar Hoover, Director, Federal Bureau of Investigation, before the House Subcomm. on Appropriations, on February 16, 1967, at 6-7 (reprint of the Library of Congress Legislative Reference Service).

143 This failure is given as one of the barriers to increased minority recruitment in the police departments by the Survey of Police-Community Relations, supra note 133, at 19-20: "[T]lhe standards which are established for entrance into the police field are designed without giving appropriate recognition to minority group differences. Written examinations may either be culture-bound or work against the Negro or Spanish-American who has limited or below average formal education. ... [C]haracter investigations and oral interviews often employ the standards of the white commurity and work to the detriment of the minority applicant." For a full discussion of recruitment standards and problems in the Newark police department, see REPORT FOR ACTION, supra note 12, at 44-52.

144 "Attitude samplings show, too, that [the average police officer] is prejudiced against Negroes and other minority groups and that he tends to be tougher in his dealings with nonwhites. He has hittle appreciation of the psychology and culture of the poor, mimorities or juveniles. He is aware that some fellow officers treat minority citizens with rudeness. abuse and even physieal roughness. He opposes full integration of his own police department." Knebel, Police in Crisis, Loor, Feb, 6, 1968, at 14. The composite profile of the "average American cop" presented in this article was gathered from studies amassed by the President's Commission on Law Enforcement and Administration of Justice.

Professor Albert Reiss, Director of the Center for Research on Social Organization at the University of Michigan was more specific in his conclusions as lie testified before the President's National Advisory Commission on Civil Disorder. Referring to extensive studies in one city, he said: "In predominantly Negro precincts, over three-fourths of the white policemen expressed prejudice or higlily prejudiced attitudes towards Negroes. Only one percent of the officers expressed attitudes which could be described as sympathetic towards 
General misunderstanding of Negroes, their needs, and their culture is intensified in riot situations. The authors of one of the field reports submitted to the President's Commission on Law Enforcement and Administration of Justice feel that the police have misunderstood the riots' causes and acted accordingly:

During the course of the field work, it became apparent that the police are both concerned and puzzled about riots. Tradition has prompted them to both perceive and respond to civil disturbances as though they are all highly-organized. ... [C]learly, most riots are not the product of a planned organization. The distinction between a spontaneous mob outbreak and an organized riot is necessary, for there should be some difference in the police response to it. ${ }^{145}$

The authors go on to suggest that this type of "spontaneous mob outbreak". requires measures less repressive than those which may be necessary to subdue an organized riot. ${ }^{146}$ Yet Cook County Sheriff Joseph Wood has made this public statement: "I have to be tough; I'm the father of eleven children. When we had our Maywood riot, I went around telling my men on the bullhorn, so all those in the street could hear, that any rioter who raised his hand above his head would be guilty of aggravated assault and should be fired on. I also told my men to shoot carefully -we didn't have extra men to take wounded off to hospitals. The bystanders got my message."147 This invitation to murder is given as an

Negroes. Indeed, close to one-half of all the police officers in predominantly Negro high crime rate areas showed extreme prejudice against Negroes. What do I mean by extreme racial prejudice? I mean that they describe Negroes in terms that are not people terms. They describe them in terms of the animal kingdom. . . "RePort of THE National Advisony Comanission on CivII Disorders 306 (Bantam 1968).

145 Survey of Police-Community Relations, supra note 133, at 350-51.

$146 \mathrm{Id}$. at 351 . Meanwhile, the Detroit pohce are now buying their own riot carbines. S.F. Chronicle, Sept. 16, 1967, at 7, col. 7. NEwsweEK, Oct. 16, 1967, at 36, reports that officials in Detroit are working up details of a proposed $\$ 2,000,000$ bond issue for new police equipment, including 1,000 army type carbines, 100 rapid fire machine guns, twentyfive infrared-equipped sniper rifles, eight armored personnel carriers, gas grenades, gas unasks and bulletproof vests. "At the same time, Police Commissioner Ray Girardin, known for strong liberal views on ghetto problems, announced his retirement, ostensibly because he had turned 65. Most observers felt Girardin was eased out for his go-slow methods during the Detroit riots, and Negroes feared his departure might herald a new tougher policy." Id.

The New Jersey Governor's Select Commission on Civil Disorder recommends that policemen be prohibited from using personal weapons in riots, REPORT FOR ACTION, supra note 12, at 388. Report of the NAtional Advisory CoAndission on Civin Disorders 492 (Bantam 1968) recommends that heavy weapons not be used in riots. See note 95 supra. The New Jersey Commission also recommends that looters, or others engaged in unlawful acts, should not be shot unless they are forcefully resisting arrest or otherwise endangering life, and that there be no mass firing at buildings that police may suspect of larboring snipers. REPORT rOR Acrion, supra note 12 , at 176 . In light of the above, however, it seems quite probable that none of these recommendations will be heeded.

147 Wills, The Second Civil War, EsquIRE, March 1963, at 81. 
example of the "new style" in police work which "can be seen everywhere." 148 It is quite obvious that many police chiefs are in no mood at present to follow the recommendation regarding the type of force appropriate to a "spontaneous mob outbreak."

The mutually lostile attitudes of the police and ghetto Negroes that are so strikingly evident during the riot situation cannot be considered in isolation, because the causes lie in the everyday contacts between the two groups. The accuracy of the charges of police brutality and the answering charges of criminality is no longer very important. The cycle of hostility exists by now whether or not the charges are true, and this cycle must be broken. The initiative in breaking the cycle must come from the police departments, because they, as organized and disciplined units, can change their attitudes and practices, while the ghetto Negroes, as disorganized and alienated individuals, cannot and will not change their attitudes until they feel that white society has given them a reason to do so. This section, then, is an attempt to describe police practices that are relevant to the riot situation, and to recommend changes in them.

The police generally see themselves as the defenders of the forces of law and order against the "moral decay" which is infecting American society. ${ }^{140}$ They feel that they have been abandoned in their war against crime, and strongly resent both open criticism and what they consider to be an over-emplasis in recent Supreme Court decisions on the rights of the individuals at the expense of the rights of society. They really cannot understand why, in the face of increasing professionalization and efficiency, many vocal sectors of society are so critical of their role:

They [the police] emphasize those aspects of their responsibilities which stress crime control. This position often clashes with many phases of our present social revolution. The police are therefore frustrated. They have made great strides from their point of view and yet they are castigated and thwarted at every turn. They are better educated and possess greater skill in the technical performance of their task, yet, they are criticized. They are far less corrupt, less brutal, and more efficient, yet, there is a call for greater civilian control. They simply do not understand such demands. ${ }^{150}$

In sum, the police regard themselves as a "beleaguered army fighting apathy and evil."151

Yet althougl local police departments resent any attempt at "outside control," whether by the courts, civilian review boards, or any other agency, they make little effort to develop comprehensive policies which

148 Id.

140 See Survey of Police-Community Relations, supra note 133, at 21-24.

$150 I d$. at 23 .

151 Id. at 24. 
will guide the individual policeman in handling the wide variety of diffcult situations, such as the riots, that require the exercise of his authority. ${ }^{152}$ There are elaborate regulations concerning various mechanical aspects of runming the department; such as proper attire and punishment for the offense of sleeping on duty, ${ }^{153}$ but surprisingly few for more important policy matters. One reason for this administrative failure is a desire to avoid direct confrontation with legislative, judicial, and constitutional standards, for fear of increased outside regulation. ${ }^{164}$ Paradoxically, this tendency to avoid confrontation has led to more outside legislative and judicial attempts to control internal police practices, since there is now a prevalent assumption that the pohce are either unwilling or unable to develop proper policies and conforming practice. ${ }^{165}$ This process becomes a vicious circle, with police laxity leading to increased outside control, and that control in turn causing increased police resentment and lack of desire to formulate regulations which conform to the new standard.

The lack of comprehensive administrative regulation is very evident in police policies regarding the use of firearms-a subject obviously relevant to the handling of riots. Many police departments have no written firearms pohicy in effect at all. ${ }^{156}$ Some of these claim some form of "oral" policy, ranging from brief one sentence statements to fairly comprehensive outlines covering at least a minimum of critical issues. ${ }^{157}$ Unwritten

152 See TASK FORCE REPORT ON THE POLTCE, supra note 97, at 16-32.

$153 \mathrm{Id}$. at 16. "There are gutidelines for the wearing of uniforms-but not for how to intervene in a domestic dispute. There are guidelines for the cleaning of a revolver-but not for when to fire it. There are guidelines for use of departmental property-but not for whether to break up a sidewalk gathering. There are guidelines for handling stray dogs-but not for handling field interrogations." REPORT OF THE NATIONAI ADVISORY COMansSION ON Civir Disorders 313 (Bantam 1968).

154 TASK FORCE RePORT ON THe POIICE, supra note 97, at 114.

155 Id. at 19. "When asked, police often are reluctant or unable to state clearly what their current policy and practice is or to document the reasons why the policy or practice is necessary for effective law enforcement. This is because there is seldom adequate commitment by police themselves to a continuous reevaluation of their own policies and practices to insure that they are both fair and effective. Because of this default it is not surprising that courts have stepped in and done the job themselves. The aeed is not for lanent over judicial intervention, but rather the development of greater police concern with the adequacy of their own programs." Remington, The Role of the Police in a Democratic Society, $56 \mathrm{~J}$. CRtar. L.C. \& P.S. 361, 364 (1965).

156 One comprehensive survey of this subject was conducted in 1961 and covered police departments in the state of Michigan. Fifty of the seventy-one departments responded to the questionnaire, and of these only twenty-two had any written firearms policy in effect at that time. A table of all findings of this survey is in Chapman \& Crockett, Gunsight Dilemma: Police Firearms Policy, PolIce, May-June, 1963, at 54-56.

157 Sixteen of the twenty-eight departments that reported no written pohicy provided some form of "oral" policy. Examples of the briefer ones include: "Quotation from law book when an officer may or may not use his revolver" (this one reported from a city of 
frearms use policies have ordinarily developed from traditional practices that are rarely the product of careful analysis, and are usually not well understood by the police. ${ }^{158}$ Most of the large American cities liave some sort of written policy on the subject, ${ }^{150}$ but they vary widely and some are clearly inadequate. ${ }^{160}$ As for in-service training on use of guns, mucli more time is spent teaching police trainees how to shoot than when to sloot and what the basis of the decision to shoot shuld be. ${ }^{101}$ Finally, too few police departments have review boards which hold inquiries as a matter of course whenever a policeman fires a gun while on duty. ${ }^{162} \mathrm{~A}$ few more will conduct inquiries if the particular incident involves certain specified elenients, ${ }^{103}$ but many have no set procedure of inquiry at all. ${ }^{184}$

over 100,000 population), and "Leave gun in holster unless they intend to use it-take shells out before handling gun." $I d$. at 55 .

158 TASK FORCE REPORT ON THE POLTCE, supra note 97, at 189.

150 A survey conducted in 1964 of forty-five of the fifty-one American cities of over 250,000 population found that only three had no written firearms policy. 1d.

100 For example, one merely prohibited warning shots, one instructed officers to "exercise the greatest possible caution," and ten urged officers to use "good judgment." Id. 161 The Michigan survey in Chapman \& Crockett, supra note 156, at 54, also included information on how much instruction officers are given in training programs on how and when to shoot their guns. Only thirty-five of the fifty responding departments reported any in-service training on when to shoot at all. The average time for cities in the lower population range spent on instructing on when to shoot was one hour and twenty-five minutes. For the one city of over 250,000 the average was two hours. The amount of time spent teaching how to shoot was six hours and thirty-three minutes, and thirty-eight hours, respectively. The police obviously spend a good deal of time learning the mechanical aspects of firearms, and very little learning whether they should use their guns in various types of situations and what the basis of that decision should be.

162 The same survey imquired into procedure followed in investigating firearms use off the shooting range. $I d$. at 54-55. Only eighteen of the fifty responding departments reported the existence of a Board of Review which held inquiries into firearms use as a matter of course.

103 In the same survey nineteen of the fifty responding departunents reported that a Board of Review would meet if the particular firearms incident involved one or more specified elements, such as property damage, injury or death, "unusual circumstances," discretion of the chief of police or another city official, negligent or illegal action, and citizen complaint. Id. at 56 .

184 The figures in notes 151-52 supra, mdicate that thirteen out of the fifty responding departments fit into this category of having no set procedure for mquiry into incidents involving use of firearms. The author of this survey had this to say about the general condition of firearms use policies: "[T] bre broad variation [in firearms use policies] reflects ... in far too many instances, a failure on the part of police administrators to provide adequate guidance for officers faced with situations where they must decide instantaneously whether or not to use their firearms in discharging their responsibilities." S. CEAPACAN, PotICE FIREARASS USE POITCT 1 (1967) (mimeo submitted to the President's Comm'n on Law Enforceinent and Administration of Justice).

The value of all the statistics mentioned in notes 156-63 supra, is limited since by now they may be outdated, and since they only pertain to the police departments in one state, except for those in the 1964 survey. However, in the absence of any comprehensive evidence to the contrary, they indicate serious faults in how police officers are trained and regulated in their use of deadly force. 
All this indicates that the internal mechanisms for instructing and controlling police officers on the use of deadly force are sadly inadequate, particularly in view of the importance of the subject. Police administrators must improve these mechanisms, both for the sake of public confidence in the police, and for the protection of the municipality and the officers from criticism and suit.

Writers on police handling of riots give little attention to the use of firearms, beyond the general decision as to whether or not they are to be employed at all. The police administrators who have written the most extensively on the subject usually limit their views on riot control to the mechanics of the situation-low to recognize potentially explosive situations, how to control the crowd, how to mobilize and what formations to use. ${ }^{105}$ All these considerations are necessary, but police leaders should give attention to the specific problenı of whether and when deadly force is appropriate. The preferable course of action would be to formulate comprehensive firearms use policies which would give guidance in all types of situations, but at least there slould be a clear policy governing use of firearms in the particularly difficult riot situation. The leaders within the police departments cannot and should not delegate this responsibility, but must meet it themselves.

\section{The National Guard}

The National Guard's performance in the Detroit riot can only be described as inadequate. General Throckmorton himself testified to this fact for the House Subcommittee on Armed Services, in August 1967: "I was confronted with a group of trigger-happy, nervous soldiers in the National Guard. I had no intention of having any of those soldiers shoot innocent people, or small clildren. And I considered the best way to handle the situation, which to my mind was not red lot at all-was to have them not load their rifles." stated that ninety percent of the guardsmen carried loaded guns in viola-

165 See, e.g., Leary, The Role of the Police in Riotous Demonstrations, 40 NOTRE DAME LAwYer 499 (1965); Wilson, Civil Disturbances and the Rule of Law, 58 J. CRDM. L.C. \& P.S. 155 (1967). The authors of these articles are the present police commissioner of New York City and the former superintendent of pohice of Chicago, respectively. The N.Y. Times, July 16, 1967, at 21, col. 5, reported that the FBI had distributed a new manual on control of riots to 35,000 of the 40,000 police agencies in the country, and that it included instructions to use only the minimum force necessary to suppress riots. The FBI has refused to release this manual to the public (and also refused to send a copy for use in this Comment), so it is impossible to say whether it differs from what police administrators usually write on riot control. The refusal to make the manual public defeats one of the main purposes in comprehensive administrative policies for the police-increased public confidence in the police because of public understanding of their regulations and the reasons for them.

166 Hearings on National Guard, supra note 14, at 5877. 
tion of the order to unload, put ammunition in pockets, and fire only on the order of a superior officer. ${ }^{167}$

Cyrus Vance, the President's Special Assistant in Detroit during the riot, felt that the troops of the National Guard were poorly trained and lacked discipline: "At the outset, the troops of the National Guard were far below the standards of the active Army in appearance, bearmg, courtesy, and general behavior; discipline was not adequate and command and control down into the ranks was poor."168 He felt that their performance improved in the course of the riot, ${ }^{169}$ but even if this is true it is no excuse for their being sent into such a difficult situation without adequate instruction or preparation.

This experience with the National Guard has not been limited to the Detroit riot. In regard to the riot in Newark, New Jersey, which occurred shortly before the one in Detroit, the New York Daily Newes had this to say about the National Guard units:

Reporters in the riot area feared the random shots of the guardsmen far more than the shots from snipers ... Once a frantic voice shouted [over the radio], "Tell those Guardsmen to stop shooting at the roof. Those men they're firing at are policemen." ... "They were completely out of their depth," said one reporter. "It was like giving your kid brother a new toy. They were firing at anything and everything." 170

Police Director Spina of Newark agreed with the tenor of this report: "I think a lot of the reports of snipers was due to the, I hate to use the word, trigger-happy guardsmen, who were firing at noises and firing indiscriminately sometimes, it appeared to me, and I was out in the field at all times." 171 Robert Conot, in his massive documentation of the Watts

107 Id. at 5892. He added: "On the corner of 12th Street there was a machinegun loaded as late as Thursday." Id. Throckmorton gave the order to unload weapons Monday night, July 24, and issued a mimeographed copy of the orders to each soldier on Wednesday night. Id. at 5881 .

168 Final Report of Cyrus Vance, supra note 13, at 51.

109 Id.

170 Quoted in T. HAYDEN, REBEIJION IN NEWARK 47 (1967).

171 REPORT FOR ACTION, supra note 12, at 136. The Commission also gave the following account of Mr. Spina's activities: "While investigating reports of sniping from the Columbus Homes, [he] observed about '200 National Guardsmen all the way down Seventh Avenue hiding behind trucks, hiding behind trees and poles and automobiles and loohing up at this project.' State troopers were also hiding behind their vehicles, and one of them told Mr. Spina that they had heard shots but that they did not know where they were from or who did the shooting. As Mr. Spina approached the last quadrangle, he saw three guardsmen running out and asked one, 'Did you fire a shot?' The guardsman rephed, 'Tes, I did.' Mr. Spma then asked the guardsman why he had fired, and he reported the guardsman as replying: 'Well, a man was close to the window and I shouted for him to duck back and he didn't so I fired a shot across the window to frighten him back inside.' Mr. Spma countered: 'Do you know what you did? You just frightened another 150 to 200 guardsinen on this street." Id. 
riot of 1965 , includes a chapter solely devoted to the deaths which occurred as a result of the Guard's panicky firing into cars at roadblocks. ${ }^{172}$ Many other incidents of the same order are scattered throughout the book.

In addition to inadequate training, there have been two main factors in the National Guard's poor performance in the riot situation. The first is the widespread panic among the guardsnien. Even during the riot, Cyrus Vance estimated the number of snipers in Detroit to be less than one hundred, ${ }^{173}$ and in the aftermath estimates ranged down to less than one dozen. ${ }^{174}$ In fact, in his report to the Army Chief of Staff, the Deputy Commander of the Army Task Force in Detroit stressed that there was very little organized sniping in Detroit:

The term sniper is used advisedly for it is not considered that there were snipers used in Detroit. A sniper is an individual who is armed with a weapon often with a telescopic sight who is highly trained in narksmanship and who hits what he aims at or accomplishes a definite purpose. In Detroit there was little evidence of real organization of a sniper force. What we had were individuals armed with rifles, sometimes under the influence of liquor firing often without purpose. 170

Mr. Vance's Final Report explained how the wild exaggeration during the riot occurred: " $[\mathrm{I}] \mathrm{n}$ the case of sniping, a single incident may be reported 8 to 10 times or more by different sources who heard a shot fired, and it appears in the police log as multiple incidents. A warning shot or the shooting out of a street light often may be reported as a sniping incident."1776 This exaggeration by the law enforcement authorities on the scene was one of the principal reasons the poorly trained guardsmen became trigger-happy.

General Throckmorton testified to the Guard's overeagerness in firing by giving this specific example:

[A]t about 4 o'clock [on Wednesday] in the afternoon, Mr. Vance and I went to 12th Street. The street was blocked off at each end and all of the entering side streets had been blocked, and I observed National Guardsnen firing their weapons over cars which would approach 12th Street from either side in an effort to get those cars to stop.

Now, there wasn't any need for this in the first place. There wasn't any reason why we shouldn't have vehicles on 12th Street, and people, and before I left there that street was open, and people were

172 R. CONOT, Rivers of BIOOD, YEARS OF DARKNesS 325-30 (1967).

173 N.Y. Times, July 27, 1967, at 1, col. 8.

174 Parmenter, Breakdown of Law and Order, 4 Trans-Acrion, Sept. 1967, at 15.

175 Hearings on National Guard, supra note 14, at 5684-85.

176 Final Report of Cyrus Vance, supra note 13 , at 49 . This exaggeration of the number of snipers by both the press and law enforcement officials is also mentioned in REPORT OF THE National Advisory Comsasston on Crvin Disorders 335 (Bantam 1968). 
coming out on the street and going about their normal business, and traffic was passing along the street as it should. ${ }^{177}$

The disastrous effect of the Guard's readiness to shoot was evidenced by the number of civilians that they killed. ${ }^{178}$

The second factor in the Guard's poor performance is the general attitude prevalent within the National Guard which designates Negroes as enemies and favors increased use of force to quell riots. A statement of Major General Almerin O'Hare of the New York National Guard exemphfies this attitude. He said that it was "entirely possible" that he would order use of liand grenades, recoilless rifles, bazookas, and other heavy weapons if the National Guard were called to New York City. ${ }^{179} \mathrm{He}$ said that to some extent the military methods used flushing guerrillas out of a village in Vietnam could be adapted to "guerilla warfare" in the ghettos, though he admitted that public opinion might not accept the use of that kind of force. ${ }^{180}$ Ironically, he added that he had given orders to his commanders to use "only the force necessary to achieve their objective and no more. ${ }^{3181}$ In a crowded urban situation, such an objective can only be wanton destruction of the civilian population. As the National Advisory Commission on Civil Disorders concluded: "[M]ass destruction weapons of nuodern warfare-flame throwers, recoilless rifles, and artillery-have no conceivable place in riot-control operations in densely populated American cities." 182

Guardsmen and other police elements have demonstrated General O'Hare's attitude in practice, as the report of New Jersey's Select Commission on Civil Disorder indicates:

There is evidence of prejudice against Negroes during the riot on the part of various police and National Guard elements. This resulted in the use of excessive and unjustified force and other abuses against Negro citizens.

The damage caused within a few hours early Sunday morning, July 16, to a large number of stores marked with "Soul" signs to depict nonwhite ownership and located in a limited area reflects a pattern of police action for which there is no possible justification. Testimony strongly suggests that State Police elements were mainly responsible with some participation by National Guardsmen. These raids resulted in personal suffering and economic damage to innocent

177 Hearings on National Guard, supra note 14, at 5889.

178 See text accompanying notes 16-1ל supra.

179 N.Y. Times, July 29, 1967, at 10, col. 6 .

180 Id.

181 Id.

182 Report of the Nationat Advisory Commission on Criti Disorders 504 (Bantam 1968). For the Commission's recommendations against use of heavy weapons by city police departments, see $i d$. at 492. 
small busmessmen and property owners who have a stake in law and order and who had not participated in any unlawful act. It embittered the Negro community as a whole at a time when the disorders had begun to ebb. ${ }^{183}$

Obviously, a great deal remains to be done on the administrative level to improve the National Guard's performance and attitude in the riot situation.

\section{B. Recommended Changes in Internal Administration}

\section{Local and State Police Agencies}

The administrative leaders within the police departments must act to fill the general gap created by the lack of comprehensive guidelines and regulations at the internal level. ${ }^{184}$ In order to deal with the riot problem, they must develop clear and comprehensive written firearms policies, discuss them thoroughly with all police officers so they will know and understand them, and develop a disciplinary procedure to handle violations. ${ }^{185}$ As on the strictly legal level, the general principles of these policies sliould be the same for riot and nonriot situations.

The firearms policies should be to make administrative regulations regarding both general principles and specific situations as clear as possible, by using simple, straightforward language which the average policeman, with no college education, ${ }^{186}$ will be able to understand easily. The police administrator should make up a set of comprehensive guidelines which fully explain both the existing law and the administrative policies regard-

183 RePORT FOR ACTION, supra note 12, at 143-44.

$184 \mathrm{~A}$ list of the many purposes that this type of administrative leadership would serve is given in TASK FORCE RePORT oN THE POLICE, supra note 97, at 19-21: (1) Allow for a certain amount of administrative flexibility, since administrative standards can be revicwed and changed to meet new conditions more quickly than legislative standards; (2) provide a sounder basis for the exercise of discretion, since the actions of individual officers would bc less arbitrary; (3) articulate definite policies and uniform practices to the public; (4) provide a means for utilizing and systemizing police experience; (5) provide a basis for disciplining those who violate administrative procedures, and serve in a positive way to inform meinbers of the force exactly what is expected of them; (6) make training more effective and realistic; (7) utilize experience, research, experimentation, and effort to define the proper rolc of the police in seciety, thus constituting an adquate basis for the developinent of the police profession; and (8) involve policemen in a decisionmaking process, which will inake them more likely to conform to the regulations both in desire and ability. Taken together, these purposes constitute an extreinely important role for the police in attempting to lessen the hostility that has grown up between them and the residents of the Northern Negro ghettos.

185 Report of tere Nationat Advisory CoMarission on Crvm Disorders 312-14 (Bantam 1968) discusses these necessary elements of the process of promulgating and disseminating clear and effective guidelines.

186 Knebel, Police in Crisis, Loor, Feb. 6, 1968, at 14, gives the lack of college cducation as one element in his composite portrait of the average American policeman. 
ing points not specifically covered by the law. ${ }^{187}$ These guidelines should instruct the police officer on how to handle all the situations which commonly face him, and include general guiding principles to govern the approach to out-of-the-ordinary, unforeseeable circumstances. If there is any change in the law, the police administrator should distribute a new set of guidehines explaining the change and its effects well in advance of the effective date of the new law. One good method to use in writing the guidelines is utilization of illustrative fact situations as examples, manipulating the terms in order to demonstrate various points, in mucli the same way as law professors use hypotheticals in their classrooins. ${ }^{188}$

Within these guidelines the definition of the term "deadly physical force" and the explanation of the requirement of reasonable belief are extremely important. ${ }^{189}$ People versed in legal thought are so accustomed to such terms that they often forget that the average police officer is not likely to know exactly what they mean. The use of legal terminology in statutory language is one of the main reasons why a simple statement of law governing deadly force in the officer's state can never be enough for purposes of guiding him. The guidelmes should also fully explain any other legalistic terms used in the relevant statutes. In addition to explaining the law itself, the guidelines must make clear the administrative policy governing situations not explicitly covered by the law, thus filling in the gaps and lesseming the confusion which results from necessarily vague and general statutory language.

The subjects of warning shots and shots to summon assistance, shots at moving vehicles, risk to bystanders, and use of deadly force against juveniles are usually not included in the present statutes regarding deadly force. In light of the above discussion regarding the proper philosophy wlich should guide police use of deadly force, ${ }^{190}$ the adininistrative policies recommended by this Comment on these subjects are fairly clear. Police should never fire warning shots or shots to summon assistance in an urban area, for the simple reason that they cannot be certain that the bullet will not hurt someone as it falls or ricochets. This risk is not worth taking unless the police officer actually has grounds to shoot at the suspect. Since this is only when he will be a threat to others if not immediately ap-

187 One fairly successful attempt at this was made by the New York Police Department in the guidelines distributed to its men before the new law regarding use of deadly force went into effect in September 1967. These guidelines are in two documents: Leary, Legal Bull. No. 8, Penal Law-Art. 35, Defenses Involving Lack of Culpability (1967) (mimeo); and Police Dep't, City of New York, Press Release No. 71, The Use of Deadly Force by Police Officers, Aug. 29, 1967 (mimeo). (Both are on file with the California Law Review.) 188 An example of this technique is found in Press Release No. 71, supra note 187, at 11-12.

189 These matters may be found in id. at 2-3.

190 See text accompanying notes 103-12 supra. 
prehended and there is no other way to apprehend him, the appropriate action is not a warning shot, but a shot to prevent the escape of the suspect, intended, of course, only to wound, not to kill. Exactly the same principle should apply regarding shots at moving vehicles, since the future course of an automobile with a punctured tire or a wounded driver is impossible to predict. As stated above, ${ }^{191}$ the policeman should never fire his gun when there is risk to bystanders except on grounds of self-defense or defense of others. As for juveniles, if the law were changed as recommended above, there would be no need to have a different pohicy regarding use of deadly force against juveniles, since the police can shoot no one unless he offers a physical threat to others if not immediately apprehended. With the law as it now is in most states, a more lenient administrative pohicy toward juveniles than others would be desirable. ${ }^{192}$

There is no reason why the general admimistrative policy on police use of firearms has to be as permissive as the statutory law of the particular state. The final report of the President's Commission on Law Enforcement and Administration of Justice recommends ${ }^{103}$ that every chief police administrator formulate a comprehensive regulation reflecting one basic policy-the police officer is to use firearms only when he believes that his life or the life of another is in imminent danger, or when other reasonable means of apprehension have failed to prevent the escape of a felony suspect whom he believes to present a serious danger to others. A project director on the staff of the International Association of Chiefs of Police has recommended that his organization adopt and enforce an administrative policy that an officer is justified in shooting at a person only when there is "clear and sufficient reason to behieve that he or someone else is about to be grievously injured or killed," or "clear and sufficient reason to believe that the person he is attempting to shoot poses an immediate threat to the safety of others, such as an arrned person desperately attempting to elude capture."104 Both of these recommended statements of administrative policy are in accord with the above recommendations on necessary changes in the law. ${ }^{195}$ If pohice departments throughout the nation adopted and enforced them, they would constitute an effective change in firearms use policy, even in the absence of statutory reform.

101 See text accompanying notes 107-09 supra.

102 Chapman, supra note 164, at $28-29$, recommends that firearms be used against juveniles only in necessary defense of a citizen's life or to preserve the life of an officer or a prisoner. This means to require that the policman use deadly force only when he has grounds to do so as a matter of self-defense or defense of others.

193 The Challenge of Crase in a Free Soctety 119 (1967).

194 Watson, A Big Question: What is your Policy on the Use of Firearms?, Police ChIEF, July, 1967, at 13.

195 See text accompanying notes 103-12 supra. 
Once the policy is formulated, police training programs should include extensive instruction and discussion on it. There should be periodic reviews even after training is completed, Every time new guidelines reflect a change, either in the law or in administrative policy regarding a situation not included in the law, the police administrator should see that they are explained to the officers with the same care as the initial policy

It is important not only that the individual officer know and understand the department's firearms use policy and the reasons behind it, but that lie realize that infractions of that policy will result in prompt and appropriate disciplinary action. An exhaustive study of the internal disciplinary aparatus appropriate to handle police infractions effectively is beyond the scope of this Comment. ${ }^{196} \mathrm{~A}$ few elements must be present in any apparatus, however, in order to effectuate the main purposes of comprehensive firearms use policies. First, a policeman's individual propensities or sense of norality nuust not interfere with his professional conduct in this sphere. ${ }^{197}$ Second, a policeman must know that consistent infraction of the firearms use policy, or, for that matter, one clearly unjustified infraction which is not simply the result of a mistake of judgment, will result in his dismissal from the force. Third, whether or not there is a civilian review board in existence, the disciplinary procedure must allow for the sympathetic reception of civilian complaints and some mechamism whereby the complainant is aware of exactly what liappens to his complaint, and the basis for the resulting action, or lack thereof. This last requirement is of prime importance. Without it one of the main reasons for the development of administrative firearms use policies-the increase of public confidence in the police-will fail.

Of course, in the last analysis it is necessary to change the attitudes of the individual officers regarding excessive use of force and, in general, law enforcement in the Northern Negro gliettos. Perhaps this can eventually be done through better education and training, increased recruitment of officers from minority groups, higlier pay for officers, and other similar measures to make the job attractive to higl-caliber, sensitive personnel. ${ }^{198}$ In the meantime, however, a change in firearms use policies in

108 For recommendations on this subject see Watson, supra note 194; Chapman, supra note 164, at 38-41; Survey of Police-Community Relations, supra note 133, at 188-247.

107 "[M]orality is a personal matter and the use of firearms is a policy matter. If an officer's personal morality is in harmony with the department's firearms policy, all the better. If not, the officer must be provided with a policy that will act as the conscience of the community to fill any void existing in personal conscience. This highlights the importance of control in ensuring that performance at the level of execution is consistent with policy." Chapman, supra note 164, at 32.

108 For a discussion of this aspect of the problem, see REPORT FOR ACTION, supra note 12, at 24-27. 
both riot and nonriot situations is absolutely necessary now, and such a change must be adequately enforced through disciplinary procedure.

The recommendations above are, if anything, more appropriate to the riot situation than to any other. If there is no consistent firearms use policy which the law enforcement authorities uniformly understand and obey, chaos and unnecessary bloodshed will continue to be the results, as they were in Detroit. Empirical evidence indicates that well disciplined city police who are very restrained in their use of deadly force can be successful in preventing a difficult situation from developing into a full scale riot. The New York police, during the summer of 1966, handled mobs by blocking thein off at various junctures, but always allowing an avenue of escape, and firing no shots, even though there was sporadic smiping. ${ }^{199}$ The disturbances lasted a week, but there was no major riot. ${ }^{200}$ Similarly, in the summer of 1967, the disturbances in Spanish Harlem did not erupt into a major riot, although they occurred simultaneously with the Detroit riot. ${ }^{201}$ In both of these instances, the Police Commissioner used a special task force, which had received extensive preparation for the riot situation, ${ }^{202}$ but there is no reason why every individual officer cannot be trained to exercise this kind of restraint and good judgment in a tense situation.

\section{The National Guard}

Judging froin the performance of the National Guard during riot situations, the above recommendations regarding comprehensive firearms use policies are even more urgently necessary for them than for the local police, because they tend to use their firearms even more indiscriminately. The added riot control training which has already been ordered for all National Guard units ${ }^{203}$ must include instructions and discussion on when it is appropriate to use firearms, and a written set of guidelines which every guardsman should know and be tested on. Because guardsmen are more likely to panic in a riot than city pohce officers, ${ }^{204}$ who liave had more experience in situations involving immediate danger, their commanding officers should give them ammunition only if it seems that they will have to use it in the immediate future.

199 TASK Force Report on the Police, supra note 97, at 193; A New Cop Approach: It Works, N.Y. Daily News, July 24, 1966 (mimeo reprint sent by Mayor Lindsay of New York City).

200 N.Y. Daily News, supra note 199.

201 See generally N.Y. Times, July 24-30, 1967.

202 N.Y. Times, July 24, 1967, at 1, col. 8; N.Y. Daily News, supra note 199.

203 Changing the Guard, Trase, Sept. 29, 1967, 24-25, reports that state National Guard units have been ordered to raise the time spent on riot control training from six to thirty-two hours per year, with additional time for officers.

204 See text accompanying notes 173-78 supra. 
The National Guard is fortunate in that it possesses the uniform disciplinary procedure of the court martial. The guardsmen must know that they will face certain court martial for any disobedience of orders regarding use of firearms, ${ }^{205}$ or for any clearly unjustified use of firearms in the absence of a direct order covering the situation. Until the National Guard has improved in its ability to handle a riot without being quick on the trigger, federal troops should be used in its stead when the local police forces cannot control the situation. ${ }^{208}$

\section{CONCLUSION}

The present state of the law gives individual law enforcenent officers broad discretion in the use of deadly force, both in and out of the riot situation. It does this by according the police the right to shoot at any fleeing felon if it is necessary to effect his arrest, and by including broadly worded statutes justifying almost any homicide incurred in the suppression of a riot. As a result of this discretion many of the people killed in the riots have been innocent bystanders or guilty of property crimes only. These deaths are not necessary to quell the riots, and they only increase the hostility and bitterness that residents of the Northern Negro ghettos feel toward the police authorities. In order to improve this situation, the generally worded riot statutes should be repealed, and the law should limit police use of deadly force. Police should understand that their proper function in using their weapons is a protective one-not punitive. Therefore, they should use deadly force only against persons who they reasonably believe will pose a threat of death or seriously bodily harm to others if not imnediately apprelended, and there is no other way to effect the arrest. This new standard is equally applicable to riot and nonriot situations and it should be promulgated in state and federal legislation. If this legislative action does not occur, the United States Supreme Court and lower federal courts should develop a federal standard along these lines as cases come to them concerning the activities of federal troops or national guardsmen during the riots. It would be even more desirable for the Supreme Court to extend the protection of the due process clause of the fourteenth amendinent to protect against summary trial and execution

205 General Throckmorton's deputy commander said: "You can't try 90 percent of the force," in his testimony before the House Armed Services Subcommittee. Hearings on National Guard, supra note 14, at 5897. If the force is so poorly disciplined that $90 \%$ of the men disobey orders, court martials of all of them, or at least of enough to serve as an example to the others, is exactly what is needed.

200 In view of the President's fear of a precedent having been set in Detroit for the federal troops to be used as local pohicing agencies, it is not likely that federal troops will ever be used in the National Guard's stead. This fact makes improvement in the quality of the Guard even more pressing. See N.Y. Times, July 25, 1967, at 20, col. 1. 
of fleeing suspects who offer no immediate danger of death or serious bodily injury to others.

Whether or not the law is changed, changes on the internal administrative level of the police departments and National Guard units can remedy mucli of the present abuse. Currently, many police departments fail to issue firm and clear instructions to officers outhining specifically when the use of deadly force is appropriate. In the confusion of a riot, such instructions should be especially clear, since the danger to large numbers of innocent people is great. The National Guard in particular, whose performance in the riots has been so undisciplined and destructive, must issue guidehines strictly limiting the situations in which guardsmen may use deadly force. Law enforcement officers must understand their instructions, and they inust follow them. Any disobedience of these orders should be punished. Law enforcement officers slould not be permitted to indulge their prejudices under cover of preserving "law and order."

People usually think of the words "law" and "order" as being as complementary as "bacon and eggs," or "salt and pepper." In fact, lowever, in a democratic society law and order may not be complementary, but rather contradictory. "In short, 'law' and 'order' are frequently found to be in opposition, because law implies rational restraints upon the rules and procedures utilized to aclieve order. Order under law, therefore, subordinates the ideal of conformity to the ideal of legality."207

A frequent response to the recent riots has been a call for allowing the police powers as much leeway as possible to repress them, and restore order. ${ }^{208}$ Proponents of this thinking see no objection to allowing the police to fire on rioters indiscriminately, because once the riot has begun the job is "not to analyse, but to end disorder."208 This approach has two serious faults inherent im it. First, a willingness to subordinate law to order, by allowing the police to punish at random, denies people in the riot area access to the orderly processes of justice and fair trial. It is possible to halt riots without resort to such an extreme measure, which only would tend to confirm the ghetto Negroes' lack of faith in the legal system and its representatives, the police. Second, the avalanche of words decrying "lawlessness" and "criminahty" tends to bury consideration of the real causes of the riots. These causes are complex and deep. Even massive efforts to solve them, which have not yet really begun, will take generations to have their full effect. It has taken over two hundred years for the bitterness among American Negroes to build up to the exploding point

207 J. SkOLNICE, JUSTICE WrinoUT TrIAI 9 (1966).

208 See Wills, The Second Civil War, EsqurRe, March, 1968, at 71.

209 Address by President Johnson to the nation, July 28, 1967, quoted in T. HAXDEN, REBELITON IN NEWARK 64 (1967). 
which began in 1965, but the bitterness has been present the whole time. It is folly to expect it to disappear overnight, even under optimum conditions.

More specifically, the police and military authorities inust realize that when they undertake the difficult task of attempting to lessen the hostibity between themselves and ghetto residents, of which the necessary changes in firearms use policies are only a part, the immediate reaction will not be one of gratitude and cooperation from all sectors of the community. It will be difficult to build up an atmosphere of mutual trust, because it requires a radical change in the attitudes of both the individual policemen and ghetto residents. These changes do not occur quickly, since the attitudes are the products of many years' experience and emotions. Yet it is exactly this type of effort that is required to save American society from racial war. Measures of repression may have a momentary calming effect, but in the end they can only intensify the bitterness and resentment, finally driving militant young Negroes into ever more desperate measures, into organized terrorism, rather than spontaneous riots. White society, in turn, will react ever more defensively to protect itself. The final result could be America's total failure to solve her "racial problems," accompanied by further subversion of the tools of her democratic processes into weapons designed to preserve order to the detriment of law.

It is this spectre of racial war in the United States, with its consequent subversion of the democratic principles that form the philosophical basis of this country's existence, that must inspire legislators, members of the legal profession and police administrators to make sincere and far-reaching efforts to lessen the hostility that exists between the police and the Negroes in the ghettos. The alternative is the destruction of American society as we know it today.

Barbara Rhine 